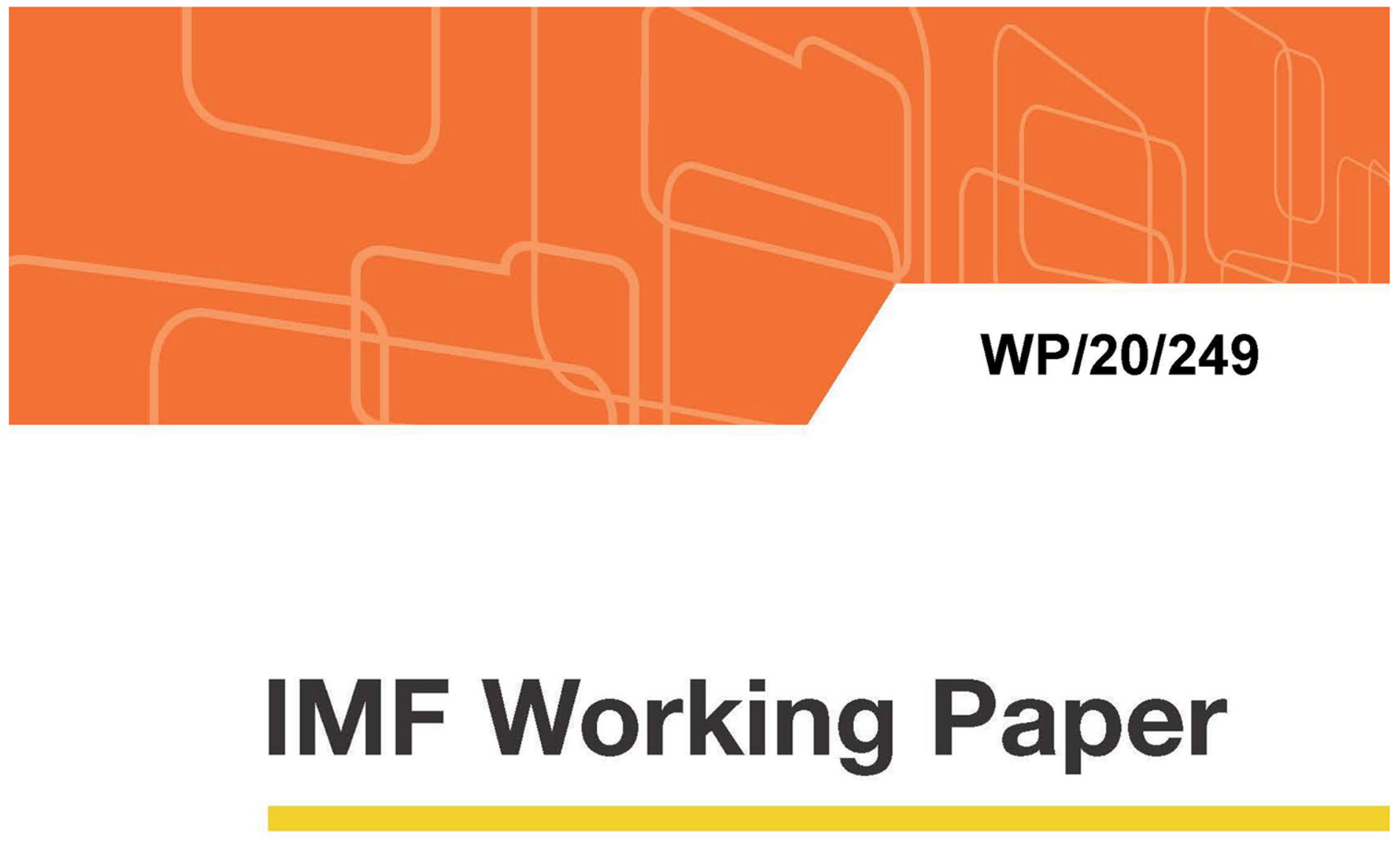

\title{
Banking Across Borders: Are Chinese Banks Different?
}

by Eugenio Cerutti, Catherine Koch, and Swapan-Kumar Pradhan

IMF Working Papers describe research in progress by the author(s) and are published to elicit comments and to encourage debate. The views expressed in IMF Working Papers are those of the author(s) and do not necessarily represent the views of the IMF, its Executive Board, or IMF management. 


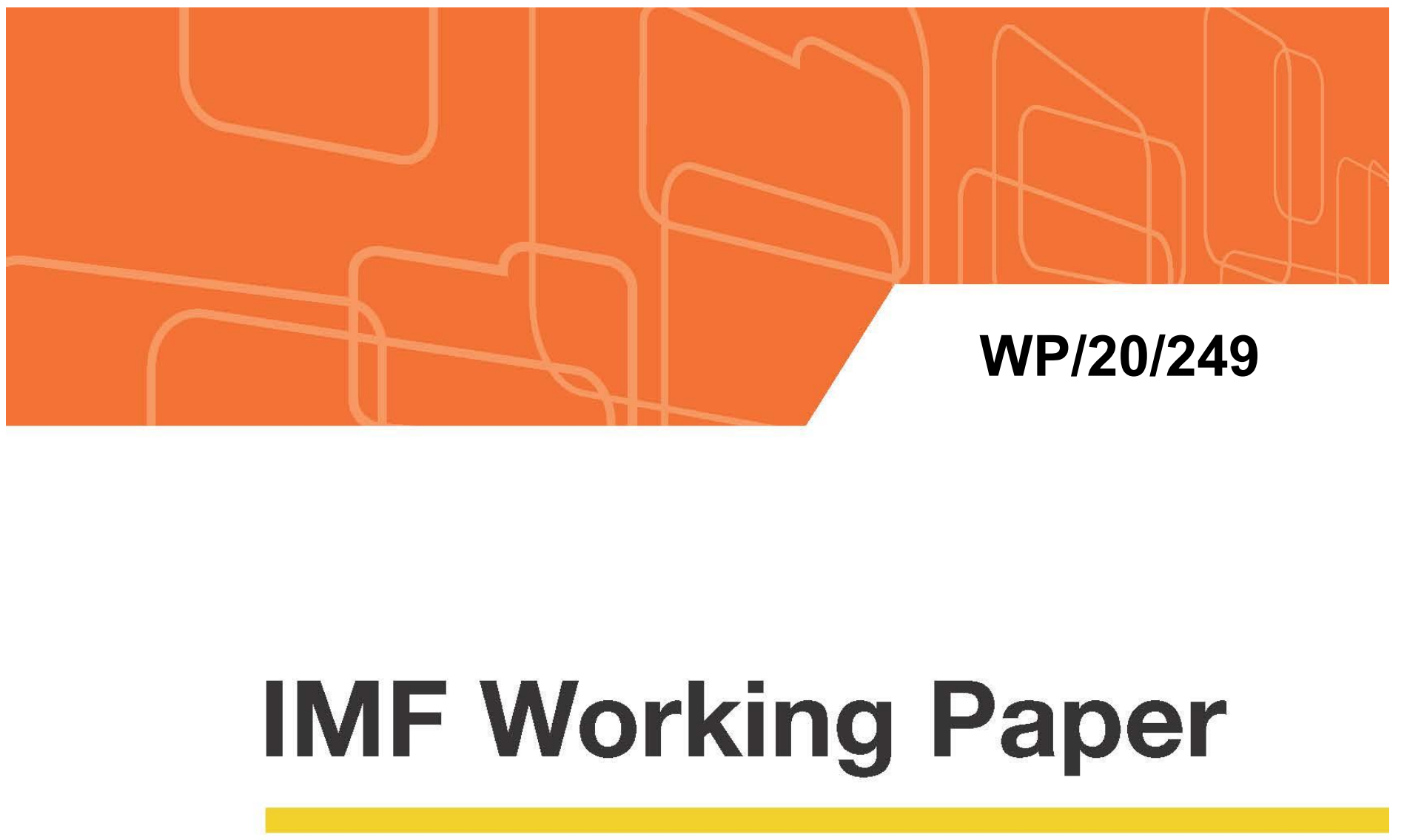

\section{Banking Across Borders: Are Chinese Banks Different?}

by Eugenio Cerutti, Catherine Koch, and Swapan-Kumar Pradhan

IMF Working Papers describe research in progress by the author(s) and are published to elicit comments and to encourage debate. The views expressed in IMF Working Papers are those of the author(s) and do not necessarily represent the views of the IMF, its Executive Board, or IMF management. 


\title{
IMF Working Paper
}

Asia and Pacific Department

\author{
Banking Across Borders: Are Chinese Banks Different? \\ Prepared by Eugenio Cerutti, Catherine Koch, and Swapan-Kumar Pradhan ${ }^{1}$ \\ Authorized for distribution by Thomas F. Helbling
}

November 2020

\begin{abstract}
IMF Working Papers describe research in progress by the author(s) and are published to elicit comments and to encourage debate. The views expressed in IMF Working Papers are those of the author(s) and do not necessarily represent the views of the IMF, its Executive Board, or IMF management.
\end{abstract}

\begin{abstract}
We explore the global footprint of Chinese banks and compare it with that of other bank nationalities. Chinese banks have become the largest cross-border creditors for almost half of all emerging market and developing economies (EMDEs). Their global reach resembles that of banks from advanced economies (AEs). We take a nationality approach as international banks, and Chinese banks in particular, grant a substantial share of their cross-border loans from affiliates located abroad. But differences remain. Using a gravity model with a novel measure of distance capturing the role of foreign affiliates across all bank nationalities, we find that larger distances deter cross-border bank lending to EMDEs more than to AEs. For Chinese banks, however, distance deters lending to EMDEs less than for peer EMDE banks. We show that for all banks combined, bilateral economic interactions like trade, FDI and portfolio investment, positively correlate with lending. Chinese banks' lending to EMDEs also strongly correlates with trade, but not with FDI and, unlike other banks, it correlates negatively with portfolio investment.
\end{abstract}

JEL Classification Numbers: F34, F36, F65, G21

Keywords: Cross-border banking, Chinese banks, Trade, FDI, Gravity model

Author's E-Mail Address: ecerutti@imf.org; catherine.koch@bis.org; swapankumar.pradhan@,bis.org

\footnotetext{
${ }^{1}$ Cerutti is at the International Monetary Fund (IMF), Koch and Pradhan are at the Bank of International Settlements (BIS). We thank Stefan Avdjiev, Katharina Bergant, Claudia Buch, Sally Chen, Michel Chui, Stijn Claessens, Mathias Drehmann, Linda Goldberg, Bryan Hardy, Thomas Helbling, Enisse Kharroubi, Patrick McGuire, Paola Morales Acevedo, Frank Packer, Kostas Tsatsaronis, Christian Upper, Goetz von Peter and participants of the BIS Research Meeting, the WEAI's IBEFA Session 2020, and the CEBRA session on "Integration or Fragmentation of Global Banking" for their comments. The views expressed in this article are those of the authors and do not necessarily reflect those of the BIS or the IMF.
} 


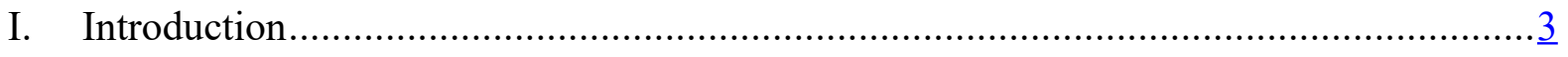

II. International Banking, Distance and Other Bilateral Economic Ties ........................... 1

A. Using Bank Nationality is Key ...............................................................

B. Taking a Bank Nationality Perspective Requires a New Distance Measure .............. $\underline{8}$

C. Cross-Border Bank Lending and Other Bilateral Economic Ties........................ 10

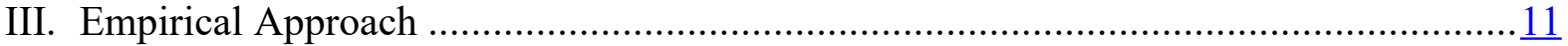

A. Simple Cross-Sectional Analysis ................................................................... 12

B. Lender-Specific Aspects Impact the Effect of Bilateral Variables ........................13

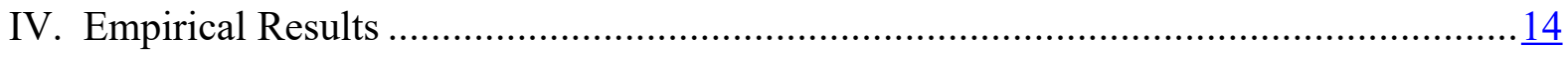

A. Simple Cross-Sectional Analysis ......................................................

B. Differences Across Lenders ................................................................ $\frac{16}{18}$

C. U.S. Dollar Denominated Cross-Border Bank Lending ................................. 18

D. Zooming in on Chinese Banks ................................................................. 19

E. Robustness Checks ...............................................................................

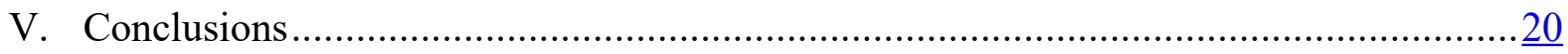

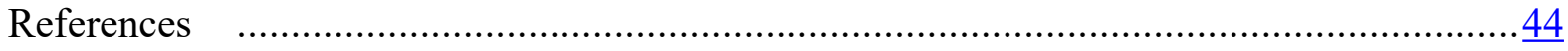

Figures

1. Simple and Weighted Distance Measures ..................................................... 23

2A. Market Shares in Different Types of International Economic Interactions with AEs .....24

2B. Market Shares in Different Types of International Economic Interactions

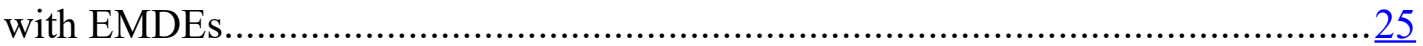

Tables

1. Measures of Global Relevance by Bank Nationality: Top Cross-Border Creditors

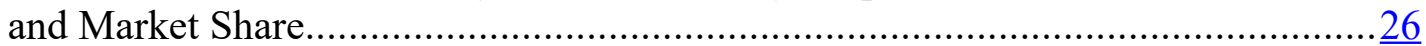

2. Descriptive Statistics ............................................................................... 27

3. Cross-Border Lending, Distance and Other Types of Economic Interaction..................28

4. Do Results Differ by Nationality of the Lending Bank? ........................................... 29

5. Do Results Differ by Nationality of the Lending Bank? U.S. Dollar Lending.................31

6. Zooming in on Chinese Banks .......................................................................... $\frac{33}{34}$

7. Alternative Estimation Methods: PPML and Keeping Zeros .................................... 34

Annex Tables

1. Cross-Border Banking, Trade and Investment: China Compared with Other Major Players in Advanced Economies (AEs) and EMDEs .........................................

2. Variable Description............................................................................. 41

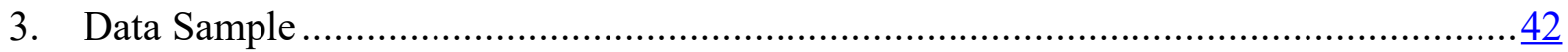




\section{INTRODUCTION}

China is the second largest economy in the world and the country's rapid rise is also reflected by the growing international footprint of its banks. In terms of total assets, China constitutes the largest banking system in the world. ${ }^{2}$ Four Chinese banks feature among the 30 largest global systemically important banks (G-SIBs) as communicated by the Financial Stability Board (FSB) after consultations with the Basel Committee on Banking Supervision (BCBS) and national authorities in November 2019. This top position among major global banking systems is mostly driven by domestic activity. However, Chinese banks have also been expanding abroad at great speed. As of mid-2018, they represent about 7 percent of total cross-border bank lending and reported claims on 196 out of 216 borrower countries according to BIS locational banking statistics (BIS LBS). More precisely, Chinese banks lend to 135 out of 143 emerging market and developing economies (EMDEs), and to 30 out of 31 advanced economies (AEs). ${ }^{3}$ Moreover, 63 EMDEs already borrow more from Chinese banks than from any other bank nationality. In this context, a better understanding of what is driving the global business of Chinese banks is key for assessing potential risks and spillovers that could arise from crises in either borrower or lender countries.

Our aim is to analyse the geographical distribution of Chinese banks' global cross-border lending and to compare Chinese with other bank nationalities. To the best of our knowledge, this is the first paper to present such analyses. We use the nationality (ultimate owner) perspective of the BIS international banking statistics instead of an approach by bank residence. More specifically, we examine the cross-border claims extended by banks from their home country, and add the cross-border claims that are issued by their affiliates located abroad. ${ }^{4}$ As highlighted by Cerutti, Koch, and Pradhan (2018), taking the global network of foreign affiliates into account is key. Across all bank nationalities, only about 60 percent of their cross-border lending is extended from their home country. The nationality perspective is even more important when studying the lending patterns of EMDE banks. On average, offices in the home country grant only about one third of their total cross-border claims on other EMDE borrowers, while the rest is granted from abroad. Thus, proceeding by bank residence instead of nationality would provide a distorted, incomplete picture.

\footnotetext{
${ }^{2}$ See IMF 2019 WEO for statistics on the size of the Chinese economy, and Cerutti and Zhou (2018b) for some banking sector measures. As of today, China is the largest banking system in the world. With $\$ 35$ trillion in total assets (about 300 percent of China's GDP), it has surpassed the U.S. banking system in 2010, and all euro area banking systems put together in the last quarter of 2016.

${ }^{3}$ Our analysis focuses on 185 borrowing countries/jurisdictions, of which 31 are AEs, 143 EMDE, and 11 are offshore centres. For 31 small jurisdictions there is no data available in terms of GDP and other bilateral ties like trade and capital flows (many may not be independent countries). We follow the BIS definition to classify advanced economies (AEs), emerging market and developing economies (EMDEs), and offshore financial centres. Annex Table 3 in this paper provides the country group classification.

${ }^{4}$ China became a BIS reporting country in 2016 (with data starting as of end-2015). Cross-border lending as used in this paper includes bank loans, holdings of debt securities and other instruments. Loans make up only about 67 percent of total claims, while debt securities account for about 22 percent as of Q3:2019. The terms lending and claims are used interchangeably.
} 
We analyze the geographical distribution of cross-border claims by using a gravity approach. These models originate from the trade literature and have been frequently applied in empirical studies of cross-border finance (e.g., among others, Aviat and Coeurdacier 2007, Buch 2002, Lane 2006, Lane and Milesi-Ferretti 2008, Porter and Rey 2005). A series of theoretical contributions has supported such models for financial holdings (e.g., Okawa and van Wincoop 2012). In our cross-sectional setup, we exploit the multiple dimensions of our data to separate borrower- and lender-specific aspects from bilateral factors. More concretely, we let individual lender- and borrower-country fixed effects absorb features that shape cross-border lending patterns from each angle. For instance, from the lenders' perspective, these control for the fact that banks from richer countries with higher financial development often lend more. From the borrowers' side, the fixed effects absorb the fact that more financially open countries typically borrow more. ${ }^{5}$

Going beyond the traditional gravity variables, we explore the role of bilateral economic ties while controlling for traditional gravity variables and a new distance measure. To capture bilateral economic ties, we let past bilateral trade, FDI, and portfolio investment enter the analysis. This is in line with how portfolio flow studies proceed using either trade or FDI (e.g., Andrade and Chhaochharia 2010, Lane 2006, and Lane and Milesi Ferretti 2008). These bilateral economic ties might help to reduce information asymmetries between borrower and lender countries. In that sense, we interpret a positive correlation between international banking and other types of economic interaction as reflecting a complementary effect. ${ }^{6}$ As traditional gravity measures of information asymmetries, we use colonial relationships, common language and the simple geographical distance between borrower and lender country. However, these traditional distance measures do not capture all aspects of the international banking business, as they ignore the location of affiliates outside of the parent banks' home country. We compute an alternative distance measure to fill this gap. It weighs, across all locations (home and/or affiliates abroad) from where a given bank nationality extends claims on a specific borrower country, each location-borrower distance by the relative importance of this location for the respective borrower-lender bank relationship. This novel distance measure ultimately provides an alternative bilateral proxy of information asymmetries.

Our analysis yields two main sets of findings. The first set relates to information asymmetries in global banking, while the second set relates to Chinese banks in specific. First, we show

\footnotetext{
${ }^{5}$ Also following the trade literature, we check whether our results could be biased given that bilateral lenderborrower links without positive cross-border lending are not included in the baseline regressions. We show that our results are robust to this type of sample bias by constructing a balanced panel with all possible bilateral lender-borrower relationships and by using the PPML estimator (Santos Silva and Tenreyro, 2006, see the robustness checks in Section IV for further details).

${ }^{6}$ The interpretation of the relationships does not imply causality since there are many two-way channels. For example, Caballero, Candelaria, and Hale (2018) show that the formation of international bank linkages can also increase exports. For bilateral portfolio holdings, Aviat and Coeurdacier (2007) argue that asset holdings may endogenously affect goods trade. When using the "substitution/complementarity" terminology, we borrow from the literature that analyses the relationship between foreign production (through FDI) and exports. The idea is to express how changes in one quantity (e.g. FDI inflows) relate to changes in another quantity (e.g., cross-border bank lending, see Blonigen (2001) for more details).
} 
that larger distances deter cross-border lending to EMDE borrowers relatively more than to borrowers in AEs. This finding pertains to most lending bank nationalities and thereby highlights the role of distance as a proxy for information asymmetries. It holds for both distance measures, but it is more pronounced for our weighted distance measure that explicitly captures the global network of banks' foreign affiliates. The stronger impact of the new distance measures suggests that the traditional, simple measure underestimates the significance of distance since it does not capture the role of geographically closer lending affiliates. In fact, the negative distance-lending correlation remains significant even after taking other measures of bilateral economic interaction, like past trade, FDI, and portfolio investment, into account. Our results suggest that past trade, portfolio investment and FDI are positively correlated with cross-border lending for the average borrower-lender bank relationship. We interpret these positive correlations as evidence of a complementary relationship that can generally reduce information asymmetries. These findings are not exclusively driven by cross-border claims denominated in U.S. dollars. Nonetheless, at the level of individual bank nationalities, our results reveal some more nuanced patterns.

The second set of results relates to Chinese banks in particular. We find that Chinese banks' expansion resembles the global reach of banks from AEs when lending to EMDEs and these results turn out be more pronounced when isolating claims denominated in U.S. dollars. In fact, Chinese banks seem to perceive distance to their borrowing EMDE counterparties as less of a barrier than other EMDE banks. In that respect, they act more like U.S. and European banks, even though most of the Chinese cross-border lending originates in stateowned banks and it is relatively more recent. With respect to other types of economic interaction like trade, FDI and portfolio investment, correlations differ, too. On the one hand, Chinese banks' positive correlation between cross-border bank lending and trade with EMDE countries stands out. It is much stronger than the trade-lending relationship exhibited by Japanese and European banks, and is again more in line with patterns exhibited by U.S. banks. This strong positive correlation between bilateral trade and cross-border lending even prevails when considering the China-specific policy initiatives like the Belt and Road Initiative (BRI) or bilateral currency swap arrangements between the PBOC and other central banks. On the other hand, unlike all other banking systems, past portfolio investment is negatively correlated with cross-border lending to EMDE borrowers in the case of Chinese banks. This seems linked to China's capital outflow restrictions and the fact that Chinese portfolio investment is mostly narrowly distributed within a few AE countries. As a matter of fact, when lending to AE borrowers, strong complementarities with portfolio investment emerge. There is only weak evidence on the relationship between Chinese FDI and cross-border lending.

Our contributions to the literature are threefold. First, our analysis provides significant evidence from international banking that supports the need to use a nationality approach when analysing global capital flows in a world with multinational entities. While using the term ultimate owner instead of nationality, Damgaard and Elkjaer (2017) or Coppola and others (2020) highlight that the presence of offshore financial centres and special purpose entities hide ultimate bilateral linkages that are necessary to understand both financial and real economic links between economies. To diagnose financial vulnerabilities, Avdjiev and others (2016) argue that the decision-making unit needs to be considered when analysing 
capital flows which are more closely related to nationality than residence in a global economy of multinational entities. Niepman (2015) offers a theoretical framework of why different banks service foreign markets to a different degree through foreign affiliates. A nationality (ultimate owner) approach also takes care of the China's "hidden" loans as revealed by Horn, Reinhart and Trebesch (2020). ${ }^{7}$ In addition, the nationality dimension lends support to our novel, more comprehensive measure of distance, as a proxy of information asymmetries. Not only do the differences between the simple and weighted distance measure indicate that lending is booked through affiliates closer to the borrowers on many occasions, but they also show that the expected negative sign for distance is more often present when we use the weighted distance measure rather than the simple distance.

Second, we complement and extend the gravity literature that links bilateral financial investments and trade to information asymmetries. We show that the distribution of crossborder bank claims varies with traditional gravity variables (e.g., distance) as well as past trade, FDI, and portfolio flows. Petersen and Rajan (2002) are among the first to explore information asymmetries in the context of the physical distance between small firms and their lending banks' organizational geographical structure in the US. On foreign banks, Mian (2006) finds that they rely relatively more on hard information while applying more conservative lending standards. As highlighted by Brei and von Peter (2018), the role of distance remains substantial for cross-border lending, even though transport costs are immaterial. Similar to Lane and Milesi-Ferretti (2008) and Lane (2006) for equity and bond holdings, we find a strong positive relationship between trade and cross-border bank lending. This is in line with the "follow the client hypothesis" of the literature of international banks" expansion (Claessens and van Horen 2015). The fact that past FDI flows also have a positive general association with cross-border banking is in line with Andrade and Chhaochharia (2010)'s use of historical FDI positions as proxy for information endowments. More related to EMDE banks, our results also seem in line with the Karolyi, Ng and Prasad (2015) finding that past trade and capital assets can generate information endowments for emerging market investors once they invest abroad. At the micro-data level, Claessens and van Horen (2020) and Caballero and others (2018) show that foreign bank presence and individual lending links matter for trade. Our results suggest that distance (especially weighted distance), trade, FDI, and portfolio investment capture different channels with respect to information asymmetries in the context of cross-border bank lending.

Third, we provide new evidence on Chinese banks, their growing footprint, and the factors associated with their cross-border lending expansion. Although there have been several studies analysing international bank activities, they have not been able to capture the global activity of Chinese banks and their affiliates located abroad. For example, Minoiu and Reyes (2013)'s analysis was based on BIS locational banking statistics (LBS) by residence before China started to report in 2016. Cross-border claims extended from offices in China did not

\footnotetext{
${ }^{7}$ Horn, Reinhart and Trebesch (2020), following the methodology by Cerutti and Zhou (2018b), calculate bilateral Chinese cross-border lending using the BIS LBS by residence. Then, they compare those estimates with other loan-based sources capturing the cross-border bank borrowing by different countries. They use the term "hidden" debt to characterize the difference between those aggregates. As highlighted in this paper and Cerutti, Koch, and Pradhan (2018), the BIS LBS by nationality provides a much more comprehensive measure of Chinese bank cross-border lending in terms of coverage and scope.
} 
enter their analysis. The paper could only indirectly reflect the cross-border lending of Chinese banks operating from Hong Kong SAR and other third countries/jurisdictions. This partial coverage of Chinese banks' lending is also present in numerous papers using the BIS Consolidated Banking Statistics (CBS), such as Cerutti and Zhou (2017, 2018a), Benetrix and others (2019) and Cheung and others (2019), since China is currently only reporting LBS data to BIS. ${ }^{89}$ In fact, the data used in our paper shows that Chinese banks' cross-border lending is not only as geographically diversified as trade and FDI, but also that China's global market share in cross-border bank lending to EMDEs is larger than in most other types of international economic interaction. This fact originates from the considerable concentration of Chinese cross-border bank lending to EMDE borrowers, from their offices at home and in other BIS reporting countries. Moreover, even though we find that the presence of swap lines between the Chinese central bank and a borrower country (but not BRI) might help explain some variation, our results highlight the importance of bilateral trade in explaining the distribution of Chinese banks' cross-border lending.

The growing international footprint of Chinese banks and their G-SIB status highlights the importance of understanding their global operations and business model. The strong positive correlation of Chinese banks' cross-border lending with bilateral trade, and their unusual current negative correlation with portfolio investment (resulting from China's low portfolio investments outside a few AEs) could interact with some ongoing macroeconomic trends. On the one hand, a prospective reduction in global trade (e.g., resulting from the shortening of value chains due to trade tensions and/or the impact of the COVID-19 virus) could be associated with a decline in Chinese cross-border bank lending, especially to EMDEs. On the other hand, the Chinese authorities' planned further integration of equity and bond markets (see Schipke, 2019) could move Chinese banks' correlation between cross-border bank lending and portfolio investment closer to the behaviour of other bank nationalities, and increase even more the reach and cross-border bank lending importance of Chinese banks.

The rest of the paper is structured as follows. Section II shows that adopting a nationality perspective requires a new measure that takes the global network of affiliates into account. It also puts bank lending into the broader context of other types of economic interaction with a specific focus on China. Section III then describes our empirical approach, while Section IV presents the main results. Finally, Section V summarizes our conclusions.

\footnotetext{
${ }^{8}$ Chinese banks operating from Hong Kong SAR are classified as "Hong Kong banks" in the BIS CBS, since they are not owned by banks from countries reporting to BIS CBS.

${ }^{9}$ There are other studies analyzing international bank activities without using BIS data, but, to our knowledge, they do not include a good coverage of Chinese banks' cross-border activities. For example, Hale (2012) and Hale, Kapan, and Minoiu (2019), using syndicated bank loan data, do not include Chinese banks' activities. Similarly, Claessens and Van Horen (2015) coverage of Chinese banks' foreign affiliates is minimal, using foreign subsidiary data from BankScope. They capture only 23 Chinese foreign affiliates ( 9 of them in Hong Kong SAR) among the more than 5,000 foreign affiliates in their sample.
} 


\section{InTERNATIONAL BANKING, Distance AND OTHER BILATERAL ECONOMIC TiES}

Our paper takes the perspective of bank nationality when analysing bilateral cross-border relationships between banks and their foreign borrowers. The recent rise in the number of BIS reporting countries offers a unique opportunity to map and analyze cross-border banking relationships worldwide not only for AE banks, ${ }^{10}$ but also for banks from EMDEs. For instance, China and Russia started to report data to the BIS locational banking statistics in 2016 with information on end-2015. Overall, our analysis builds on bilateral relationships between 39 lender countries and up to 185 borrower countries. This section first describes global lending patterns from a nationality perspective in more detail to highlight the need for a new measure of bilateral borrower-lender distance. It then puts bank lending into the broader context of other types of bilateral economic interaction between borrower and lender countries, with a specific focus on China.

\section{A. Using Bank Nationality is Key}

Taking a nationality perspective paints a more complete, undistorted picture of global banking than the frequently used concept of residence. According to the nationality perspective in the BIS locational banking statistics, claims of resident banks in different reporting jurisdictions are attributed to the home country of banks. We choose the bank nationality perspective for two reasons. First, it has a more comprehensive coverage. As pointed out by Cerutti, Koch and Pradhan (2018), across all lender bank nationalities, about 60 percent of their cross-border claims are extended from their home country, while 27 percent are extended from offices in host AEs, about 11 percent are extended from host offshore centers and the rest from offices in other host EMDEs. When banks of EMDE nationalities make cross-border loans to borrowers in other EMDEs, only about one third is booked from their respective home country. ${ }^{11}$ Second, for some hubs of international banking like the U.K. and Hong Kong SAR, the residence perspective would capture a blend of different nationalities. Also, it would mask the fact that a large share of offshore business is actually conducted from elsewhere, again distorting the measurement of the bilateral lenderborrower business relationships. In this respect, foreign banks account for about 92 percent of all cross-border claims booked from offshore financial centers vis-à-vis all borrowers worldwide. A split reveals that AE banks make up about 65 percent, while EMDE banks represent 27 percent of these foreign banks.

\footnotetext{
${ }^{10}$ As highlighted in BIS (2019), the definition of "banks" conforms to other widely used definitions, such as "Deposit-taking corporations, except the central bank" in the System of National Accounts (SNA) and in the Balance of Payments Manual (BPM6); "other (than central bank) depository institutions" in the IMF money and banking statistics. In the case of China, BIS LBS data does include the Export-Import bank of China and China Development Bank, but not the insurance corporation Sinosure. The definition for inclusion is being a deposittaking institution. Some other countries also include mortgage and financial institutions that are licensed as credit institutions, as this license permits them to accept deposits even if they do not do so.

${ }^{11}$ We do not include local claims (claims of affiliates abroad on the residents where the affiliates are located) in our calculations, because those claims tend to be locally funded (Cerutti 2015).
} 


\section{B. Taking a Bank Nationality Perspective Requires a New Distance Measure}

As a proxy of information asymmetries, an appropriate distance measure should take the global network of affiliates into account. In this context, a traditional simple distance measure captures the bilateral geographical distance between the country of loan origination and the country where the borrower resides. However, this distance measure might be inappropriate by ignoring the difference between home offices and the global network of affiliates located in third countries abroad. In principle, if distance was a perfect proxy for information asymmetries in banking, and banks always tried to minimize information asymmetries, there should always be only one optimal location from which a bank should lend to a particular borrower. Within each bank holding company, that would be the affiliate that was most closely located to the ultimate borrower. ${ }^{12}$

Our novel measure of weighted distance takes into account the full network of affiliates for each pair of borrower country and lending bank (by nationality), while summing across all locations including the home country. Formally, the weighted distance measure is computed as

$$
\operatorname{Dist}_{l b}=\sum_{r=1}^{R} \operatorname{Dist}_{r b}\left(X B C_{l r b} /_{X B C_{l b}}\right)
$$

with $l$ denoting the parent country for each lending bank nationality, $r$ referring to residence(s) from where banks of nationality $l$ can extend credit, and $b$ referring to countries that borrow from banks of nationality $l$. Hence, $\operatorname{Dist}_{r b}$ stands for the bilateral distance between residence $r$ from where credit to borrowers in country $b$ is granted. More precisely, bilateral distance Dist $_{r b}$ captures the distances between the capitals of the borrower and the residence countries from where the lending banks grant cross-border loans. Further, $\left(X B C_{l b r} /_{X B C_{l b}}\right)$ represents the portfolio weight as a relative share of residence $r$ in the global total of all cross-border lending extended by banks from parent country $l$ to borrowers in country $b .{ }^{13}$ For each lender-borrower pair, we sum across all residences to obtain a measure at the level of individual lender-borrower relationships that matches our empirical setup.

On average, banks tend to prefer lending through foreign affiliates that are located closer to the borrower than their home country. Figure 1 compares the mean of both distance measures for each bank nationality, across all AE borrowers in the top panel, and across all EMDE

\footnotetext{
${ }^{12}$ In our paper, we only use a cross-sectional approach and hence take the existence of foreign affiliates as given. Buch and others (2014) show that only the largest and most productive banks open affiliates abroad as there is a fixed cost of market entry. Based on microdata of German banks they show that greater distances and activity restrictions deter banks, while more developed financial markets attract more lending.

${ }^{13}$ We drop backflows from the entire computation (i.e., claims on the home country that are intermediated by offices located abroad). These lending flows capture aspects of the funding structure and do not reflect the global expansion and customer business of banks.
} 
borrowers in the bottom panel. If the simple distance (red dot) is above the weighted distance measure (blue dot), Figure 1 indicates that banks book claims through foreign affiliates located closer to the borrower, on average. Substantial differences between both measures emerge for those bank nationalities whose home countries ${ }^{14}$ are located on the periphery of financial flows. ${ }^{15}$ When extending claims to borrowers in AEs, banks from Australia, Brazil and the U.S. often use their foreign affiliates to book these claims. On average, when lending to EMDEs, the difference between the simple and the weighted distance measure seem to be less pronounced. Only for U.S. banks does the difference increase. With respect to Chinese banks, they seemingly prefer booking their claims on AEs from offices closer to these borrowers. When cross-border lending to EMDEs, a substantial share seems to be extended either by mainland offices, or by affiliates that are geographically close, like those located in Hong Kong SAR, Macao SAR, or Singapore.

\section{Cross-Border Bank Lending and Other Bilateral Economic Ties}

The global footprint of Chinese banks is considerable, especially regarding EMDE borrowers. For the largest banking systems, Table 1 shows the number of countries for which banks of a particular nationality are the most important creditor as well as their market shares. It distinguishes between total cross-border bank lending to all borrower countries (top panel), AE borrowers (center panel) and EMDE borrowers (bottom panel), respectively.

At the global level, Chinese banks are the most important creditor for 66 (out of 185) borrower countries, more than any other banking system. However, even though Japanese banks lend to fewer borrowing countries than other nationalities, they report the highest individual country market share (15.4 percent) in global cross-border lending. They are followed by U.S. (11.3 percent), French (11.3 percent), U.K. (9.5 percent), Chinese (7.1 percent), and Swiss banks (6.4 percent). While the market share of Chinese banks in cross-border lending to AEs is small, about 2.4 percent, when turning to EMDE borrowers, the order almost reverses. Now, Chinese banks rank the highest when it comes to market shares. They extend about 24 percent of total cross-border bank lending to EMDE borrowers, more than double that of Japanese banks, which are the second largest individual bank nationality in this market (11.2 percent). Out of 143 EMDEs, Chinese banks are also the most important creditor for almost half, namely 63 borrower countries, more than six times larger than the 10 EMDEs for which French banks count as the most important lender. The statistics for the other creditor nationalities are shown in Annex Table 1.

${ }^{14}$ For European banks the differences between the means of simple and weighted distances are small, except for U.K. banks' lending to EMDE borrowers. This seems to capture the fact that a lot of the U.K. banks' lending to Asia is performed from U.K. bank affiliates located in Hong Kong SAR or Singapore (McGuire and Van Rixtel, 2012).

${ }^{15}$ In principle, note that it could be the case that foreign affiliates could be located even further away from the borrower country than the banks' headquarters. If the average weighted distance was above the simple distance, this would clearly call into question whether distance is an appropriate proxy for information asymmetry in international banking. Other reasons like different tax codes or location-specific features might play a role. However, only in some isolated cases (lending banks from Greece and Turkey) do both measures almost coincide for AE borrowers and generate weighted distance measures that slightly exceed simple distances for EMDE borrowers. 
What about other bilateral economic ties? In addition to cross-border bank lending, we consider three types of other bilateral economic interactions between the lending parent banks' home and the borrower country. First, we consider bilateral trade as the sum of exports and imports as reported by the lender with respect to the borrower country (e.g., capturing imports by China and exports from China). Second, we use outward FDI. To match the "by nationality" perspective of the BIS data, we follow Damgaard and Elkjaer (2017), who adjusted FDI data to reflect the ultimate investor perspective. Third, portfolio investment enters the analysis, featuring both debt securities and equities holdings as captured by the IMF Coordinated Portfolio Investment Survey (CPIS). ${ }^{16}$

The market shares of the largest bank nationalities' in other types of international economic interaction vary considerably. The low market share of Chinese banks' cross-border lending to $\mathrm{AE}$ borrowers is similar to the Chinese low shares in FDI and portfolio investments. However, the country's large market share in international trade stands out. As shown in Figure 2A, the U.S. holds the highest market share in FDI and portfolio investment with business partners in other AEs, and similar shares in trade as the U.S., Japan, Switzerland, U.K., and France have larger shares in cross-border banking than other bilateral economic ties.

The role of China is much larger with respect to EMDEs. China features among the dominant players in all markets except for portfolio investment (Figure 2B). While China plays the most important role in FDI and cross-border lending, the U.S. dominates portfolio investment in EMDEs. The market shares in international trade are above cross-border banking in the case of China, France, US, and Japan. The market share of China in terms of portfolio inflows is almost nil since China's portfolio investments are concentrated on a few AEs.

\section{EMPIRICAL APPROACH}

This section presents our empirical approach. We start with a simple cross-sectional analysis to explore the bilateral correlations between international banking on the one side, and gravity variables and other types of international economic activities on the other. In a second step, we examine how lender-specific aspects might impact these correlations. The figure below illustrates the setup of our dataset. To mitigate endogeneity concerns, our regression analysis draws on lagged values for trade, total portfolio investment and FDI.

\footnotetext{
${ }^{16}$ With respect to portfolio investment, we do not separate between equity and debt securities in order to maximize the number of bilateral observations. Many bilateral observations are not available when downloading portfolio equity and securities investments from IMF CPIS dataset separately (e.g., due to confidentiality issues). Results for smaller samples breaking down portfolio equity and securities investments do not significantly change our results with respect to portfolio investment.
} 


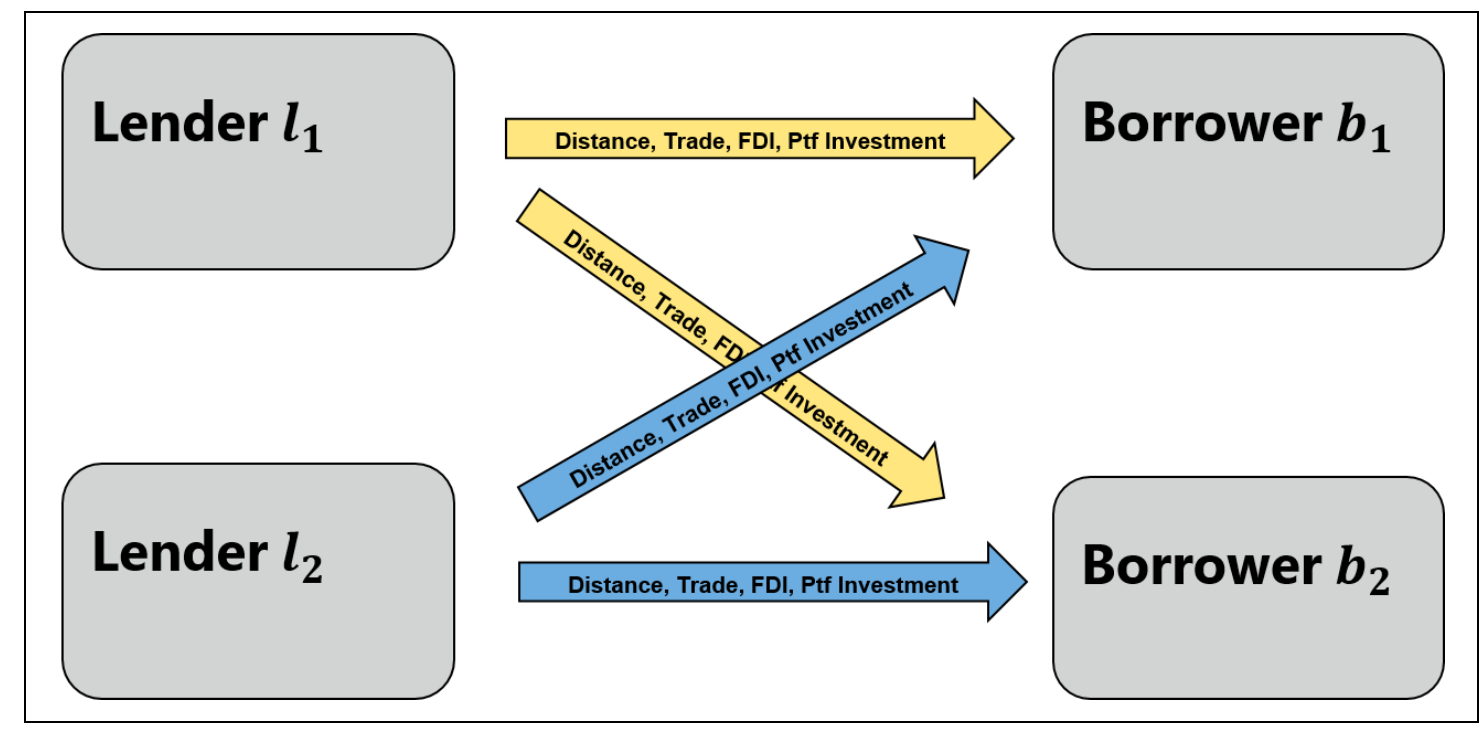

\section{A. Simple Cross-Sectional Analysis}

Recent theoretical contributions have shown that bilateral financial asset holdings follow patterns that are similar to those revealed by gravity models in the trade literature. In this context, we draw on Okawa and van Wincoop (2012) and Lane and Milesi-Ferretti (2008), while adjusting their gravity framework to our setup with bilateral cross-border claims:

$$
\begin{gathered}
\ln \left(X B C_{l b}\right)=\alpha+\beta_{d} \ln \left(\text { Dist }_{l b}\right)+\boldsymbol{\beta}_{\boldsymbol{g}}^{\prime} \text { OtherGRAVITY } \\
+\boldsymbol{l b}+\boldsymbol{\beta}_{\boldsymbol{e}}^{\prime} \ln \left(\boldsymbol{E C O N}_{\boldsymbol{l b}}\right) \\
+\boldsymbol{F E}\left(\boldsymbol{P C} C_{\boldsymbol{l}}, \boldsymbol{B C}_{\boldsymbol{b}}\right)^{\prime}+\varepsilon_{l b}
\end{gathered}
$$

In our baseline specification (1), we let $\ln \left(X B C_{l b}\right)$ denote the logged outstanding stock of bilateral cross-border lending of the parent country $l$ on borrower country $b$. We borrow from the gravity literature to find proxies for time-invariant information asymmetries that might hamper cross-border lending. First, geographical distance between lender and borrower country can act as a catch-all proxy for all kinds of informational frictions $\ln \left(\operatorname{Dist}_{l b}\right)$. Besides the standard distance measure that captures the bilateral distance between the capitals of borrower and lender country, we use our weighted distance measure. This novel distance measure fits the nationality point of view by taking into account that a cross-border loan can be extended by an affiliate located in a third country that is different from the lender's home country itself. If this location of the affiliate was geographically closer to the ultimate borrower, the weighted distance measure would be smaller (see Section II.B). We challenge both distance measures by adding societal and historical aspects. The vector OtherGRAVITY $\boldsymbol{l l}_{\boldsymbol{l}}$ introduces two other indicators, one for colonial relationships after 1945, Colonial $(0 / 1)_{l b}$, and the other signals if the borrower and lender countries share the same language, Common Language $(0 / 1)_{l b}$.

Apart from the time-invariant gravity variables, we consider three other types of bilateral economic interaction between the lender and the borrower country. These bilateral economic ties might also foster cross-border bank lending by reducing informational frictions and thereby act as complements. Following the literature on the geographical distribution of 
portfolio holdings, vector $\ln \left(\boldsymbol{E} \boldsymbol{C O} \boldsymbol{N}_{\boldsymbol{l b}}\right)$ captures the logged volume of bilateral trade as the sum of imports and exports, $\ln \left(\operatorname{Trade}_{l b}\right)$, total portfolio investment referring to debt plus equity investment, $\ln \left(\right.$ Investment $\left._{l b}\right)$ and $\mathrm{FDI}, \ln \left(F D I_{l b}\right)$. As a way to address potential endogeneity concerns, we lag these economic relationship variables by at least one year.

To properly identify the impact of bilateral variables, we use two sets of fixed effects. In particular, we let lender nationality fixed effects absorb general differences in the propensity to extend cross-border lending (e.g., richer countries with better-developed financial systems, global financial centers, current-account surplus countries that persistently export savings, etc.). Separate borrower country fixed effects soak up country-specific aspects like average creditor quality, characteristics of the local banking system, economic size, etc.

\section{B. Lender-Specific Aspects Impact the Effect of Bilateral Variable}

Our aim is to explore whether some parent banks are special by revealing patterns that deviate from the common effect of informational frictions on cross-border bank lending. To identify these deviating patterns, we interact the proxies of information asymmetries with a vector of parent country indicators $\boldsymbol{C}_{l}(\mathbf{0} / \mathbf{1})^{\prime}$. For general frictions, we let the interacted distance term $\left(\ln \left(\text { Dist }_{l b}\right) * \boldsymbol{C}_{\boldsymbol{l}}(\mathbf{0} / \mathbf{1})\right)^{\prime}$ captures this differential impact. For economic ties that could potentially reduce information asymmetries, we interact past trade, FDI, and portfolio holdings with a vector of bank nationality indicators $\boldsymbol{C}_{\boldsymbol{l}}(\mathbf{0} / \mathbf{1})$. In particular, we flesh out countries $l$ of parent banks that are headquartered in China, other EMDEs, the U.S., Japan and Europe against a residual category that captures banks from other AEs like Australia and Canada, as well as offshore financial centres like Hong Kong SAR and Singapore. ${ }^{17}$

$$
\begin{aligned}
& \ln \left(X B C_{l b}\right)=\alpha+\beta_{d} \ln \left(\text { Dist }_{l b}\right)+\boldsymbol{\beta}_{\boldsymbol{e}}^{\prime} \ln \left(\boldsymbol{E C O N}_{\boldsymbol{l b}}\right) \\
& +\left(\boldsymbol{\gamma}_{\boldsymbol{d l}}{ }^{\prime} \boldsymbol{C}_{\boldsymbol{l}}(\mathbf{0} / \mathbf{1}) * \ln \left(\text { Dist }_{l b}\right)\right)+\sum_{k=0}^{3}\left(\boldsymbol{\gamma}_{\boldsymbol{l k}}{ }^{\prime} \boldsymbol{C}_{\boldsymbol{l}}(\mathbf{0} / \mathbf{1}) * \ln \left(E_{\text {CON }}^{k}\right)\right)+\boldsymbol{F} \boldsymbol{E}\left(\boldsymbol{P} \boldsymbol{C}_{\boldsymbol{l}}, \boldsymbol{B} \boldsymbol{C}_{\boldsymbol{b}}\right)^{\prime} \\
& \quad+\varepsilon_{l b}
\end{aligned}
$$

Overall, our analysis builds on bilateral relationships between up to 39 lender countries and up to 185 borrower countries. Table 2 provides some descriptive statistics. More detailed definitions and data sources of our variables are presented by Annex Table 2. For cross-border bilateral claims denominated in all currencies, the average outstanding stock reaches US\$4 billion, while the median is at US\$20 million. Other measures of bilateral economic interactions are also very skewed. The average volumes of bilateral trade and portfolio investments amount to about US\$5 billion and US\$8 billion, respectively, while

\footnotetext{
${ }^{17}$ Europe captures the main EU banking systems namely BIS reporting countries from the euro area and the U.K. Our main findings remain intact when using alternative groupings of parent countries. In a series of robustness checks, we always keep China separate while changing the baseline category and isolating other bank nationalities. Accordingly, we combine U.S. and Canadian, as well as Japanese and Australian banks. Further, we add other European banking systems (NO, SE, DK and $\mathrm{CH}$ ) to the group of European countries. By doing so, only offshore financial centers are left in the residual group. This robustness check turns out to be a re-scaling exercise in that our findings on Chinese banks remain almost entirely unaffected and most other results remain intact, as well.
} 
their median values only reach US\$243 million and US\$12 million. As traditional gravity variables, our baseline analysis draws on geographical distance and two other bilateral indicator variables capturing common colony and common language. Finally, while 14 percent of our bilateral country pairs indicated that they speak a common language, only 2 percent are linked by historical colonial ties.

\section{EMPIRICAL RESULTS}

Our empirical analysis proceeds in several steps. We start by exploring how cross-border bank lending broadly correlates with gravity variables and other types of bilateral economic interactions. Within the set of gravity variables, we provide a novel comprehensive analysis on the role of distance (simple and weighted), trade, FDI, and portfolio flows as proxies of information asymmetries. In the second step, we examine whether the effect of distance and other types of economic activity on cross-border lending differs by bank nationality. In the third step, we isolate cross-border claims in U.S. dollar to see whether our results are driven by a particular currency denomination. Finally, we restrict the view to Chinese banks and examine the impact of policy initiatives like the BRI or bilateral Swap arrangements with the PBOC on cross-border lending patterns. A series of robustness checks shows that our main findings prevail even when controlling for a potential bias that could arise in the context of zero outstanding amounts.

\section{A. Simple Cross-Sectional Analysis}

Among the traditional gravity variables, distance plays the most important role in the geographical distribution of cross-border lending. As we are interested in bilateral borrowerlender relationships, we let borrower and lender fixed effects absorb any unilateral aspects as described in the cross-sectional specification in equation (1). The baseline gravity regression is restricted to simple distance, colonial ties and common language, and reveals the familiar findings from the trade literature (Table 3, upper panel, column 1). More precisely, higher bilateral distances go along with lower levels of outstanding bilateral cross-border bank claims. By contrast, colonial relationships and common language are associated with higher bilateral outstanding amounts between borrower and lender countries. ${ }^{18}$

Going beyond the traditional gravity approach, our expanded framework suggests that other types of bilateral economic ties seem to act as a complement when studying the geographical distribution of cross-border lending. Columns 2 to 4 show the results when considering bilateral lagged trade, portfolio investment and FDI, one at a time, while columns 5 to 9 take them jointly into account. ${ }^{19}$ Positive correlation coefficient estimates suggest that higher bilateral trade, total portfolio investment and FDI are associated with higher amounts of

\footnotetext{
${ }^{18}$ We have also estimated the impact of other traditional gravitational variables like similarities in legal and economic systems, other geographical characteristics, political relationships etc. To arrive at a parsimonious specification, we limit our focus to the most significant ones that revealed to be robust across a number of specifications. Results on other variables are available on request.

${ }^{19}$ To the best of our knowledge, our paper is the first one to test together the correlation of trade, FDI, and portfolio investment with cross-border bank lending.
} 
bilateral cross-border lending. The positive correlation signs with the international economic variables indicate complementarities between international banking and other types of economic interaction. These complementarities could be driven by different motivations. One such motivation might be a "follow your customer considerations" (Buch 1999, Claessens and van Horen 2015). Another motivation might be that the other economic ties reduce information asymmetries between borrower and lender, in the sense of the information endowments presented by Andrade and Chhaochharia (2010).

The additional benefit from having traditional gravity variables other than distance in our specification might be limited. Even though the literature suggests that traditional gravity variables, such as language and historical colonial relationships, reduce information asymmetries, they do not contribute additional information in our cross-sectional setup (beyond what is already captured by distance, trade, portfolio investment and FDI). In fact, when dropping the commonality indicators, the adjusted R2 declines only marginally. Only the distance measure continues to play a key role after controlling for past trade, FDI, and portfolio investment as shown by the R2 differences between columns 5 and 6 (Table 3 ). Across all borrowers and lenders, a 1 percent rise in bilateral borrower-lender distance is associated with a 0.62 percent decline in cross-border lending. From here on, we drop the gravity indicators of common colony and language, from our cross-sectional specification (column 6) in order to save presentational space. Yet the results are comparable if included.

Borrowers in AEs and EMDEs imply different risk-return trade-offs for the lending banks that go along with different levels of complementarity. For borrowers in AEs, a 1 percent rise in trade is associated with a 0.77 percent increase in cross-border lending (column 7). For borrowers in EMDEs, this rise is about 0.63 percent. The positive correlation of portfolio investment and FDI is weaker, but also more similar for AEs and EMDEs. A 1 percent increase in total portfolio investment goes along with a 0.35 percent rise in lending to AE borrowers, and a 0.31 percent for EMDE borrowers, respectively. The impact of FDI is weaker (0.05-0.06 percent) and only marginally significant for EMDE borrowers. When distinguishing AE from EMDE borrowers, distance seemingly only matters for EMDE borrowers. By contrast, the distance effect carries an insignificant positive coefficient for borrowers in AEs. ${ }^{20}$ This finding suggests, that economic ties can reduce information asymmetries relatively more for borrowers in AEs than for borrowers in EMDEs.

Yet, is our measure of simple distance appropriately capturing international information asymmetries in international banking? An appropriate measure should take the complex intermediation structures in global banking into account. To address this issue, we use the new distance measure introduced in Section II that explicitly captures the global network of affiliates located outside of the banks' home country.

\footnotetext{
${ }^{20}$ Relative results are similar when considering the distribution of the economic variables. A one standard deviation increase in trade is associated with an increase in cross-border bank lending of about 1.8 standard deviations, 1.1 standard deviations in the case of portfolio investment, and 0.1 standard deviations in the case of FDI.
} 
Results based on the weighted distance measure see some significant changes when distinguishing between different groups of borrower countries (Table 3, bottom panel). The complementarities with trade, portfolio investment, and FDI remain unaffected when controlling for weighted instead of simple distance. Yet, the coefficient estimate on weighted distance for AE borrowers turns negative and significant at the 10 percent level, which is more in line with the traditional interpretation of distance as a proxy of information asymmetries. For lending to EMDEs, the distance coefficient raises in size and remains statistically significant.

In sum, our results at this stage highlight that distance, especially when taking into account weighted distance, is a general key factor underpinning the current geographical distribution of global cross-border lending. Unlike other traditional gravity variables, it plays a role even after controlling for past trade, FDI, and portfolio investment. The correlation of other economic ties with international banking are also significant, and they imply interesting complementarities. These complementarities seem to play out stronger for borrowers in AEs than for borrowers in EMDEs. For the rest of this paper, we will focus on the weighted distance measure when describing the regressions and only report the simple version of distance for the sake of comparison.

\section{B. Differences Across Lenders}

Do all bank nationalities that extend cross-border lending exhibit the same patterns? Is there anything special about banks from EMDEs, and Chinese banks in particular? To answer these questions, we build on the full sample regression from columns 7 and 8 in Table 3, but we now interact the distance and economic relationship variables with an indicator of parent bank nationality as described by equation (2). At the level of individual bank nationalities, our results reveal some more nuanced patterns.

While cross-border lending declines if bilateral weighted distance increases across all bank nationalities, there are differences across borrowers and lenders. Table 4 shows that the impact of distance is more pronounced for EMDE borrowers than for borrowers from AEs. On average, a 1 percent increase in distance is associated with a 0.43 percent drop in outstanding cross-border claims on AE borrowers (Table 4, column 2). For EMDE borrowers, this drop reaches 0.67 percent (Table 4, column 4).

Chinese banks seem to perceive distance to their borrowing EMDE counterparties as less of a barrier than other EMDE banks. The interaction effect of our weighted distance measure and the Chinese bank indicator is insignificant, but the standalone coefficient persists (Table 4, column 4). This result also holds for claims extended by U.S. and European banks. By contrast, larger distances deter banks from other EMDEs and Japan relatively more. The sum of the standalone and the interaction coefficient indicates that a 1 percent increase in weighted distance reduces outstanding amounts by more than 1 percent for both types of lenders. In this context, Chinese banks' large expansion not only resembles the global reach of banks from the U.S. and Europe, but also in their sensitivity to distance when their global network of affiliates is considered. 
When turning to AE borrowers, bank nationalities also differ in their sensitivity to information asymmetries. Chinese, European and banks from other EMDEs do not significantly deviate from the standalone coefficient. However, a remarkable contrast emerges for Japanese banks, as larger distances effectively increase cross-border lending to AE borrowers due to the country's remote geographical position and the operations of its international affiliate network. ${ }^{21}$ At the same time, the cross-border lending to AEs by U.S. banks seems to be almost insensitive to changes in distance. The sum of standalone and interaction terms suggest that distance has almost no effect: a 1 percent increase is associated with outstanding stocks that are about 0.07 percent lower. ${ }^{22}$

Stronger trade relationships go hand in hand with more cross-border lending. Table 4 confirms these findings and it also underlines that trade plays a similar role for borrowers in EMDEs and AES, on average. A 1 percent increase in bilateral trade is associated with a 0.57 percent rise in lending to AEs(Table 4, column 2), and a 0.52 percent raise in lending to EMDEs (Table 4, column 4), respectively.

Chinese banks' positive correlation between cross-border bank lending and trade with EMDE countries stands out. When lending to EMDE borrowers, the complementary impact of trade turns out to be even stronger for lending by both Chinese and U.S. banks. The sum of standalone and interaction coefficients for these lenders suggests that a 1 percent increase of cross-border trade is almost matched with a 1 percent increase in cross-border lending. The fact that the sensitivity of Chinese banks' cross-border lending to EMDEs is similar to U.S. banks also with regard to trade is particularly interesting taking into account that most Chinese banks are state-owned unlike U.S. banks (Allen and others 2012). The complementarity is a bit weaker for European and Japanese lenders, and the weakest for banks from other EMDEs. When lending to AE borrowers the effects are less pronounced for Chinese, U.S. and Japanese banks. For Chinese banks, a 1 percent rise in bilateral trade raises their outstanding claims by only 0.4 percent.

On average, portfolio investment also seems to complement bilateral cross-border bank lending relationships -- almost to an equal extent for borrowers in AEs and EMDEs. Bilateral country pairs that exhibit a 1 percent higher level of portfolio investment also see 0.37-0.38 percent higher level of outstanding cross-border claims, as revealed by the standalone coefficient estimate. Nonetheless, results are also nuanced for some parent bank countries, especially in the case of China, which deviates from this pattern when lending to EMDEs. For EMDE counterparties, bilateral claims extended by Chinese banks are 0.21 percent lower. By contrast, for AE counterparties, if bilateral portfolio investment raises by 1 percent, Chinese banks report a 0.76 percent higher level of outstanding bilateral

\footnotetext{
${ }^{21}$ As suggested by Figure 1, the weighted distance measure clearly differs from the simple distance measure for Japanese lenders. This highlights the importance to take the global affiliate network into account. The interaction coefficient for Japanese banks would lead to the opposite, conclusion when relying on the simple distance measure.

${ }^{22}$ In the case of Japanese banks, the large differences in the estimated interaction effects of distance between using simple and weighted distance is driven by the large volume of lending to AE borrowers that is booked from 29 different reporting locations.
} 
amounts. Capital outflow controls in China are most likely driving this sharp contrast. As shown in Figure 2 and Annex Table 1, the market share and the geographical distribution of Chinese portfolio investment are much lower, and concentrated on AE countries. One might also interpret this finding in the light of information asymmetries in that Chinese banks, unlike other banking systems, do not benefit from reducing information asymmetries through portfolio investment.

As a function of the respective parent bank nationalities, FDI has a largely heterogeneous relationship with cross-border bank lending. On average, a 1 percent increase in FDI is associated with a 0.11 percent rise in cross-border bank lending, independent from whether the borrower resides in an AE or an EMDE (Table 4). However, substantial differences emerge for some parent bank nationalities when turning to FDI in EMDEs. The net effect of a 1 percent rise in bilateral FDI is associated with a 0.17 percent decline in lending to EMDE borrowers originated by Japanese banks. For Chinese and U.S. banks, the decline is much lower, about 0.05 percent and 0.03 percent, respectively. When turning to AE borrowers, the net effect of bilateral FDI is marginally positive for Chinese, U.S. and other EMDE banks, but almost zero for European and Japanese banks.

\section{U.S. Dollar Denominated Cross-Border Bank Lending}

When restricting the focus to U.S. dollar denominated claims, most relationships turn out to weaken slightly, but for Chinese banks our core findings become even more pronounced.

Tables 5 replicates Table 4, while considering only the subset of cross-border claims that are denominated in U.S. dollars. Remarkably, the effect of distance as a proxy of information asymmetries turns insignificant for cross-border lending to AE borrowers, on average. For borrowers in EMDEs, it remains only marginally significant. By contrast, bilateral economic ties still seem to complement international banking. Trade continues to play the most important role in offsetting information asymmetries when lending in U.S. dollars to AEs, but for lending to EMDE borrowers, the relationship between portfolio investment becomes more important. We interpret the differences between AE and EMDE borrowers in light of the fact that most types of business from trade to financial investments with EMDEs are still denominated in U.S. dollars. As opposed to that, cross-border lending as well as other types of financial flows and trade among AEs is more likely to take place in other currencies like the euro or the pound.

Chinese banks' sensitivity to information asymmetries as proxied by distance seem to be more pronounced when restricting the focus on US-dollar denominated lending. The net effect of a 1 percent increase in bilateral distance to an EMDE borrower is associated with a 0.94 percent decline in U.S. dollar claims, and similar in magnitude to the net effect exhibited by banks from other EMDEs. Only for Japanese banks does bilateral distance have an even more negative impact on their lending to EMDEs. Turning to borrowers in AE, there is no effect of distance on U.S. dollar lending neither for Chinese, nor for European banks. For Japanese banks, it seems that U.S. dollar-denominated claims contribute to the effect previously described for lending to AEs in all currencies: the net effect of distance is positive which can be explained by the geographical structure of its affiliate network. In the context of U.S. dollar claims, U.S. banks' cross-border lending to AEs is special as they act as key funding sources in their home currency. 
In terms of bilateral economic relationships, differences with respect to trade stand out again. Chinese banks display the strongest complementarity with respect to EMDE borrowers. A 1 percent increase in bilateral cross-border trade is associated with an almost 1.2 percent increase in U.S. dollar claims of Chinese banks on EMDE borrowers. This rise is only about 0.6 percent in the case of U.S. banks and Japanese banks. This difference between Chinese and other EMDE banks is even larger for U.S. dollar claims than in the case of total crossborder claims. Two aspects might help to explain this finding. First, it might be related to the fact that a lot of bilateral trade is still invoiced in U.S. dollar (see Gopinath and others 2020). Second, Chinese banks play an important part in trade finance vis-à-vis EMDE borrowers. When granting loans in U.S. dollar to borrowers in AEs, the effect of trade becomes very small for Chinese banks.

In terms of portfolio inflows, the contrasting patterns that Chinese banks showed for lending to $\mathrm{AE}$ and EMDE borrowers persists. Complementarities are again particularly strong for portfolio investment when extending cross-border claims to borrowers in AEs, but not so for lending to EMDEs. Evidence on the relationship between FDI and Chinese banks' lending is again weak and ambiguous.

\section{Zooming in on Chinese Banks}

This strong positive correlation between bilateral trade and cross-border lending prevails when considering the China-specific policy initiatives. Up to now, we have highlighted the differences between Chinese banks and banks from other parent countries. At this stage, we restrict the sample to Chinese banks and their borrowers from EMDEs. We then analyse whether some China-specific international policy initiatives impact Chinese banks' crossborder lending. More specifically, we use a dummy variable that indicates whether a particular EMDE that participates either in the BRI initiative as of 2015 (Table 6, columns 1 to 4) or whether it has a bilateral swap-line arrangement with the PBOC (columns 5 to 8). We add these dummies to our baseline specification (1) and interact the policy indicator with distance, trade, portfolio investment and FDI, respectively.

In this very narrow subset of observations, trade is the only economic relationship variable that displays a positive and statistically significant relationship with cross-border bank lending. The negative coefficients for portfolio investment are in line with our full sample regressions, but they are not statistically significant. While the BRI indicator is not statistically significant itself, neither on a standalone, nor on an interacted basis, the swapline indicator is only marginally significant. The lack of significance of the BRI relationship could be related to the fact that it is positively correlated with trade and trade already absorbs any potential contribution from BRI.

\section{E. Robustness Checks}

Our main results are robust to a number of tests. For instance, we test whether there was a bias that could arise from the fact that we have several bilateral lender-borrower links without positive cross-border lending. Why does the issue arise in the first place? When creating our sample, many zeros emerge as we allocate 185 potential borrower countries to 
each reporting country, and ultimately to each of the 39 considered bank nationalities. In the context of BIS data, each reporting country submits its claims on the universe of all possible counterparty borrower countries worldwide, while distinguishing between domestic and foreign banks with a split by foreign bank nationality. We have access to the full dataset. Even if data points are flagged as confidential or restricted on the BIS website, they enter our analysis, but they are not available to a broader audience. Hence, in our dataset a missing value indicates that no outstanding amounts exist, and thus missing values essentially correspond to zeros.

The presence of zero outstanding cross-border amounts inflates our sample and could create a problem for the use of log linear models in the context of gravity equations, since the zeros might not be randomly distributed. To alleviate concerns that these zeros bias our results, we follow the steps taken in recent papers, for instance by Caballero and others (2018) or Claessens and van Horen (2020). First, we estimate the Poisson Pseudo-Maximum Likelihood (PPML) estimator (Table 7, columns 1 to 4) as presented in Santos Silva and Tenryro (2006). Second, we replicate the Table 4 regression while adding a small positive dollar amount to those relationships with zero reported outstanding amounts to avoid dropping these observations when taking logs (Table 7, columns 5 to 8). In both cases, the stand-alone variables have the expected signs when looking at the weighted distance measure and the results confirm our previous findings: negative coefficients for distance and positive correlation coefficients for trade, portfolio investment, and FDI. These results are mostly statistically significant, especially when considering EMDE borrowers. The specific results for Chinese banks are also similar. Chinese banks, compared to other nationalities, lend relatively more to EMDE borrowers with higher bilateral trade. Similar to other EMDE banks, distance is also more negatively correlated with Chinese bank lending to EMDE borrowers.

\section{CONCLUSIONS}

This paper studies the global footprint of Chinese banks and compares it with that of other major bank nationalities. Global banks extend cross-border claims and operate networks of foreign affiliates that can propagate shocks when crises occur in either borrower or lender countries. Chinese banks' cross-border lending is sizeable, reaching 18 percent of the country's GDP. Chinese banks' business is also relatively focused, as 43 percent of their total lending goes to EMDE borrowers. In terms of market share, Chinese banks account for 24 percent of all cross-border lending to EMDE borrowers, more than double that of Japanese banks, the second largest competitor (making up 11 percent of the EMDE total). Further, almost half of all EMDE borrower countries rely on Chinese banks as their most important lender.

Our paper proceeds on the basis of bank nationality by exploring a unique dataset that captures the cross-border operations of the banks' home offices and their global network of affiliates located abroad. Taking a nationality perspective is important to understand financial and real economic links between different economies as highlighted by Damgaard and Elkjaer (2017), or Coppola and others (2020). The multiple dimensions of the BIS locational banking statistics allow us to distinguish between more than 5000 lender-borrower pairs both from AEs and EMDEs. These data dimensions also allow us to create a new distance 
measure as an alternative proxy of information asymmetries. Across all locations from where a given bank nationality extends claims to a specific borrower country, it weights distances by the relative importance of each location for the respective lender-borrower relationship. To examine how banking relates to other economic ties, we have combined the BIS statistics with data on trade and international capital flows. We explore the bilateral correlations between banking and other types of economic interaction as they might complement each other by reducing bilateral information asymmetries.

Our analysis yields two main sets of findings. The first set pertains to all bank nationalities combined, while the second explicitly focuses on Chinese banks. Accordingly, our first set of results shows that lenders are much more sensitive to distance when extending claims to borrowers in EMDEs than to borrowers in AEs. This finding highlights persistent information asymmetries and it still holds after considering that a loan can be made by an affiliate located outside of a bank's home country. We also find that the negative distancelending relationship remains significant after controlling for other bilateral economic ties between the borrower and the lender that could potentially reduce information asymmetries. In fact, our results show that past trade in particular, but also portfolio investment and FDI frequently can act as complements to cross-border lending, in the sense of revealing positive correlations.

The second set of results suggests that Chinese banks' global operations resemble the global operations of banks from other major AEs when lending to EMDE borrowers. In terms of complementarities, bilateral trade between China and its EMDE borrowers stands out. Our results show that the positive effect of trade persists even when considering China-specific policies like the Belt-and-Road Initiative, or bilateral Swap arrangements that China's central bank, the PBOC, initiated with other central banks. When lending to borrowers in AEs, strong complementarities with portfolio investment emerge. There is also some evidence that Chinese FDI can act as a complement to cross-border banking with AEs. This effect, however, disappears when isolating cross-border claims that are denominated in U.S. dollars.

Our paper provides three main contributions. First, it supports the need to follow a nationality approach in the analysis of global business operations as banks from EMDEs, and China in particular, grant a substantial share of their cross-border lending from abroad. Second, it extends the literature on bilateral financial ties and information asymmetries by presenting a new distance measure that takes the global network of affiliates into account, and by highlight the role of other economic ties in reducing information asymmetries. Third, it contributes to a better understanding of China's role as a lender in international capital markets, and in particular for borrowers from EMDEs.

Our findings provide some interesting policy implications. On the one hand, if trade tensions or the aftermath of the COVID-19 crisis translate into a persistent decline in global trade, we could expect cross-border bank lending to fall in parallel. In fact, the decline in global banking could be more pronounced for Chinese banks as they display significantly higher correlations than some of their peers. On the other hand, the ongoing and planned liberalization reforms in the Chinese bond market could foster further inward and outward portfolio investment. If the liberalization of portfolio investment makes China more similar 
to other AE and EMDE countries, Chinese banks' investments abroad could surge in an attempt to further diversify. This could lower information asymmetries for Chinese cross-border bank lending.

Future research might explore which China-specific factors might play significant roles. For instance, although our analysis highlights broad resemblance with AE banks when lending to EMDE borrowers, the government's considerable ownership shares in the largest Chinese banks could play an important role on geopolitical and economic aspects (e.g., state-owned banks lent relatively more during the global financial crisis as they pursued an objective of helping to stabilize the economy, as shown in Bosshardt and Cerutti, 2020). As of now, our results are constrained by the cross-sectional nature of our empirical approach. Future research might benefit from a longer time series, as China only started to report to the BIS locational banking statistics with positions from Q4:2015. 


\section{Figure 1. Simple and Weighted Distance Measures ${ }^{1}$}

(By bank nationality; distance in km; cross-border lending in all currencies)

Borrowers in advanced countries

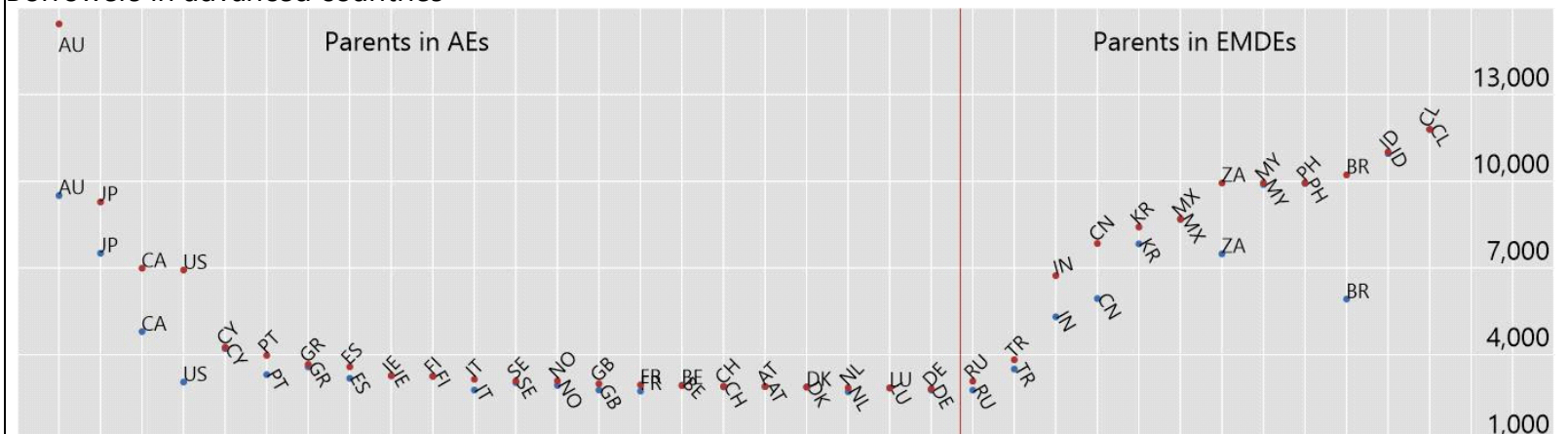

$$
\text { - Simple distance Weighted distance }
$$

Borrowers in emerging market economies

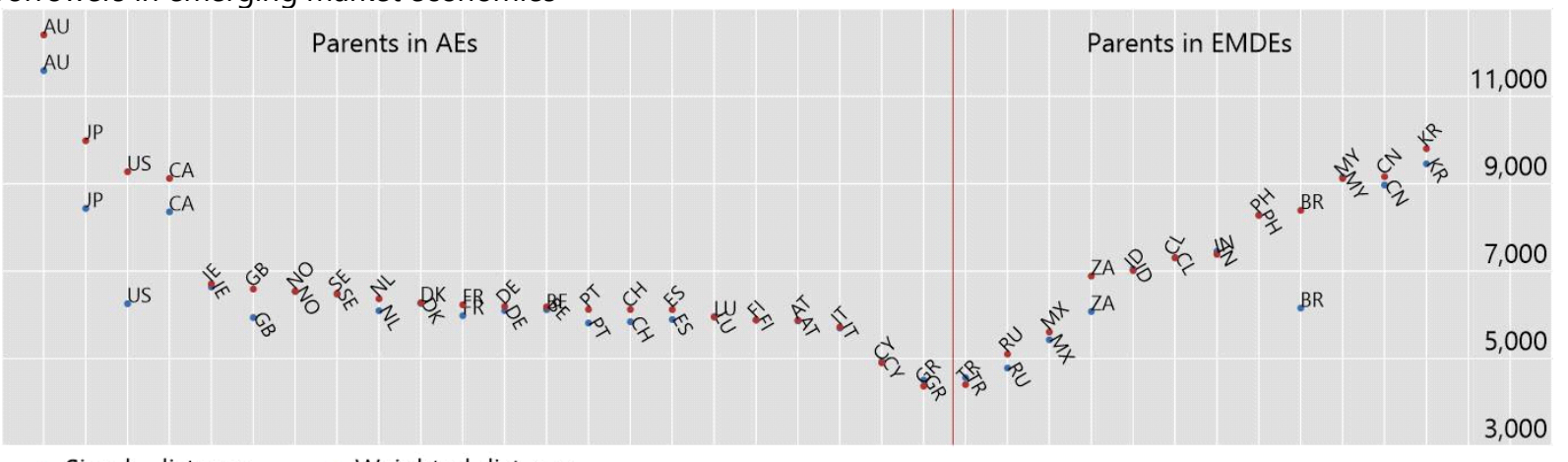

\section{- Simple distance - Weighted distance}

Sources: BIS locational banking statistics (by nationality); CEPII database; authors' calculations.

1 For each depicted parent bank nationality, simple distance is the simple average across all pairs of distances from the respective capital of the lending banks' parent country (nationality) to the respective capital of borrowing countries. Weighted distance for each depicted bank nationality is the simple average across all pairwise weighted distance measures. Each pairwise weighted distance measure sums across all locations from where a given bank nationality extends claims to a specific borrower country, while weighting distances by the relative importance of each location for the respective lender-borrower relationship. Formally, the weighted distance measure is computed as Dist $l_{l b}=\sum_{r=1}^{R} D_{i s t} t_{r b}\left(X B C_{l b r} /_{X B C_{l b}}\right)$ with $l$ denoting the parent country for each lending bank nationality, $r$ the residence(s) of lending banks outside of their home country, and $b$ the borrowing country. Hence, $D_{i s t} r_{r b}$ stands for the distance in $\mathrm{km}$ between location $r$ from where the bank $l$ lends to borrowers in country $b$, and $\left(X B C_{l b r} / X B C_{l b}\right)$ represents the portfolio weight as relative share of bank $l$ 's offices in location $r$ in the global total of all cross-border lending extend by lending banks $l$ to borrower country $b$. We drop backflows from the entire computation (ie lending to the home country that is extended by offices located abroad). These lending flows capture aspects of the funding structure and do not reflect the global expansion and customer business of banks. 
Figure 2A. Market Shares in Different Types of International Economic Interactions with AEs ${ }^{1}$

(As a share total vis-à-vis AE counterparties)

China

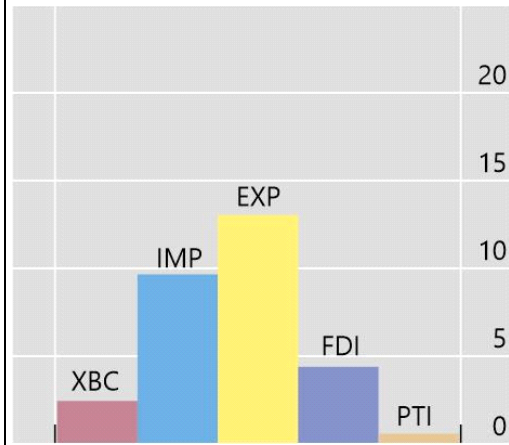

Switzerland

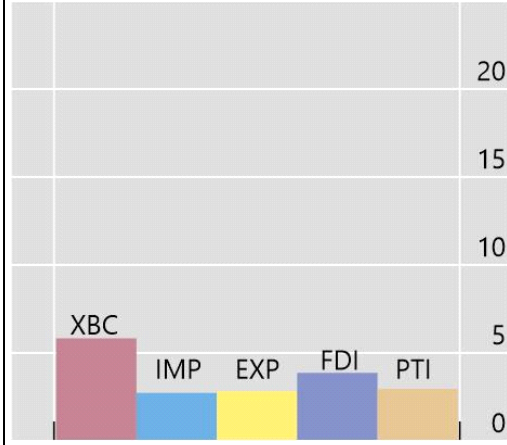

United States

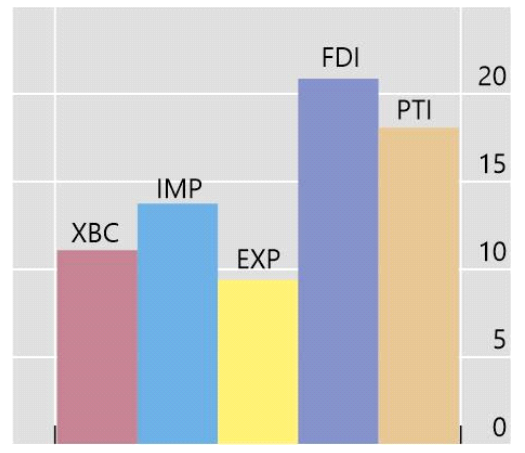

United Kingdom

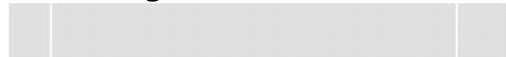

20

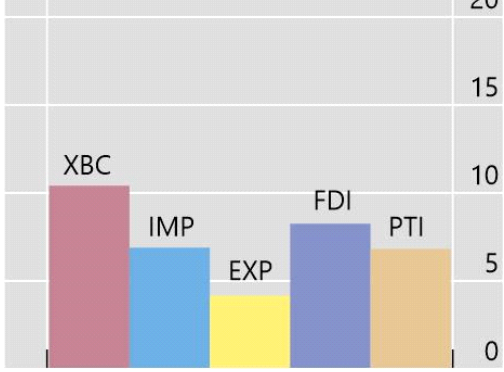

Japan

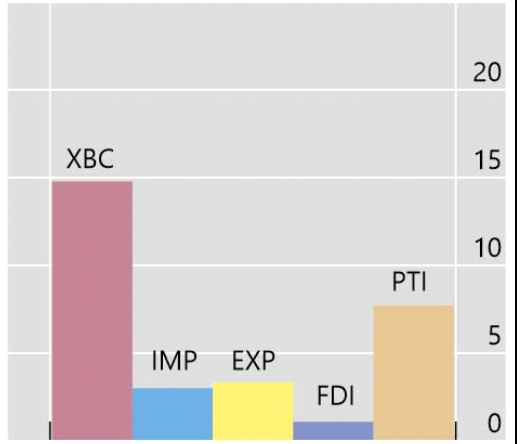

France

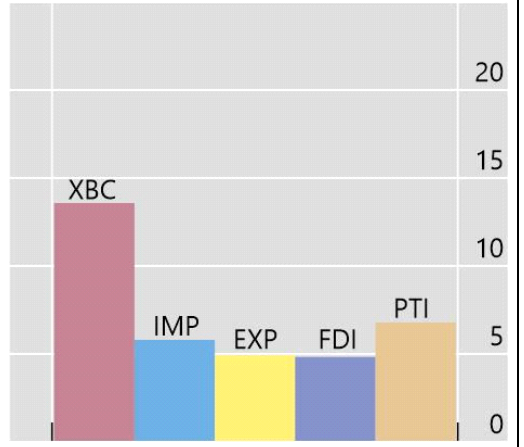

Sources: BIS locational banking statistics (by nationality); CEPII database; and authors' calculations.

$\mathrm{XBC}=$ Cross-border lending in all currencies, by bank nationality; IMP = Imports; $\mathrm{EXP}=$ Exports; FDI $=$ Foreign direct investment, by nationality; PTI = Portfolio investment.

1/ Annex Table 2 provides variable description 
Figure 2B. Market Shares in Different Types of International Economic Interactions with EMDEs ${ }^{1}$

(As a share of total vis-à-vis all EMDE counterparties)

China

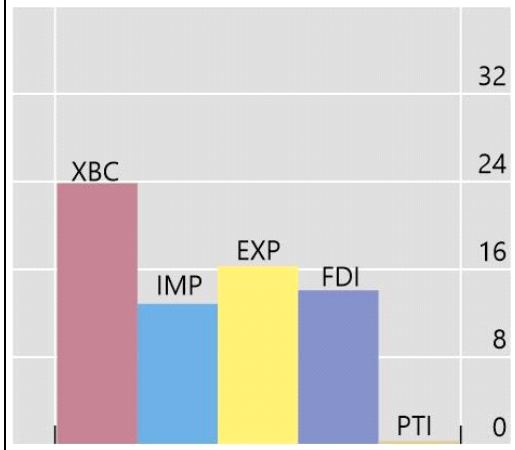

Switzerland

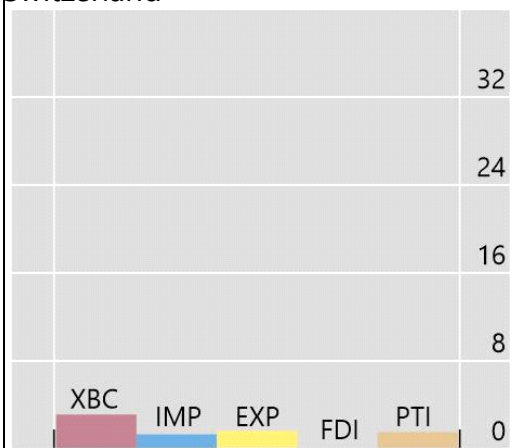

United States

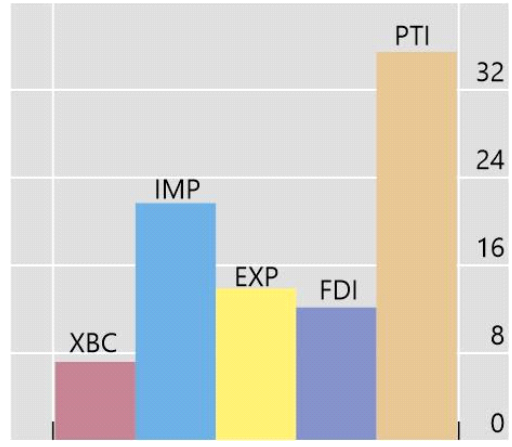

United Kingdom

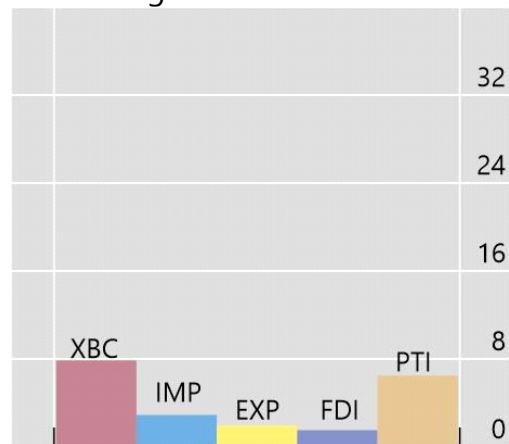

24

8

0
Japan

32

France

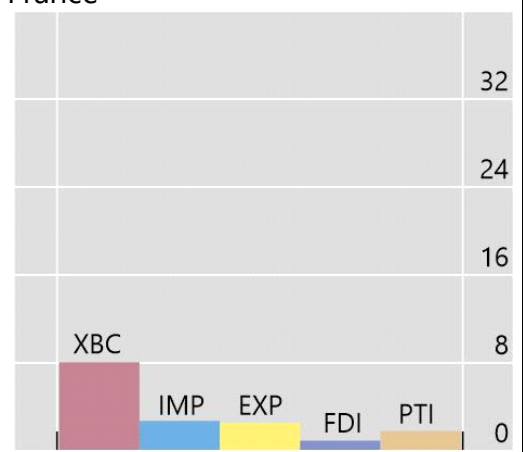

Sources: BIS locational banking statistics (by nationality); IMF; World Bank; and authors' calculations

$\mathrm{XBC}=$ Cross-border lending in all currencies, by bank nationality; IMP = Imports; EXP = Exports; FDI = Foreign direct investment, by nationality; PTI $=$ Portfolio investment.

1/ Annex Table 2 provides variable description 
Table 1. Measures of Global Relevance by Bank Nationality: Top Cross-Border Creditors and Market Share

(Excluding claims of foreign affiliates on home country, as of Q2:2018)

\begin{tabular}{|c|c|c|c|c|c|c|}
\hline & CN banks & JP banks & US banks & UK banks & $\mathrm{CH}$ banks & FR banks ${ }^{2}$ \\
\hline \multicolumn{7}{|l|}{ Borrowers Worldwide(185) ${ }^{1}$ : } \\
\hline Number of borrower countries & 176 & 136 & 156 & 175 & 179 & 175 \\
\hline Total credit (US\$ billions) & 2,101 & 4,540 & 3,318 & 2,808 & 1,875 & 3,341 \\
\hline Share in total outstanding (\%) & 7.1 & 15.4 & 11.3 & 9.5 & 6.4 & 11.3 \\
\hline $\begin{array}{l}\text { Number of countries for which } \\
\text { banks are the top creditor }\end{array}$ & 66 & 11 & 11 & 5 & 7 & 16 \\
\hline \multicolumn{7}{|l|}{ Borrowers in AEs(31) ${ }^{1}$ : } \\
\hline Number of borrower countries & 30 & 30 & 30 & 31 & 31 & 31 \\
\hline Total credit (US\$ billions) & 488 & 2,953 & 2,215 & 2,081 & 1,164 & 2,715 \\
\hline Share in total outstanding (\%) & 2.4 & 14.8 & 11.1 & 10.4 & 5.8 & 13.6 \\
\hline $\begin{array}{l}\text { Number of countries for which } \\
\text { banks are the top creditor }\end{array}$ & 0 & 3 & 1 & 0 & 1 & 6 \\
\hline \multicolumn{7}{|l|}{ Borrowers in EMDEs(143) ${ }^{1}$ : } \\
\hline Number of borrower countries & 135 & 98 & 115 & 133 & 137 & 133 \\
\hline Total credit (US\$ billions) & 919 & 434 & 277 & 303 & 120 & 312 \\
\hline Share in total outstanding (\%) & 23.7 & 11.2 & 7.1 & 7.8 & 3.1 & 8.1 \\
\hline $\begin{array}{l}\text { Number of countries for which } \\
\text { banks are the top creditor }\end{array}$ & 63 & 6 & 9 & 5 & 4 & 10 \\
\hline \multicolumn{7}{|c|}{ Sources: BIS locational banking statistics (by nationality); authors' calculations. } \\
\hline \multicolumn{7}{|c|}{$\begin{array}{l}1 \text { The number of borrower countries in our estimation sample is } 185 \text {, while the total number of borrower countries that } \\
\text { potentially exists in the BIS data is } 216 \text {. As some of these countries have missing observations in the other datasets, we lose } 31 \\
\text { mainly very small jurisdictions. }\end{array}$} \\
\hline \multicolumn{7}{|c|}{$\begin{array}{l}2 \text { Shares and numbers of French(FR) banks are the highest among euro area reporting nationalities. The } 12 \text { other euro area } \\
\text { bank nationalities that report to the BIS are Austria, Belgium, Cyprus, Finland, Germany, Greece, Ireland, Italy, Luxembourg, } \\
\text { Netherlands, Portugal and Spain. }\end{array}$} \\
\hline
\end{tabular}




\begin{tabular}{|c|c|c|c|c|c|c|}
\hline \multicolumn{7}{|c|}{ Table 2. Descriptive Statistics } \\
\hline Variables ${ }^{1}$ & $\mathrm{~N}$ & mean & p50 & $\mathrm{sd}$ & $\min$ & $\max$ \\
\hline \multicolumn{7}{|l|}{ All counterparties } \\
\hline Total lending, $\ln (X)$ & 5,090 & 2.69 & 2.97 & 4.32 & -6.91 & 14.00 \\
\hline USD lending, $\ln (X)$ & 3,712 & 3.01 & 3.40 & 3.92 & -6.91 & 13.93 \\
\hline Colony $(0 / 1)$ & 5,090 & 0.02 & 0.00 & 0.15 & 0.00 & 1.00 \\
\hline Common Language $(0 / 1)$ & 5,090 & 0.14 & 0.00 & 0.35 & 0.00 & 1.00 \\
\hline Trade, $\ln (X+1)$ & 5,090 & 5.48 & 5.50 & 2.70 & 0.00 & 13.30 \\
\hline Investment, $\ln (X+1)$ & 5,090 & 3.39 & 2.53 & 3.56 & 0.00 & 14.30 \\
\hline FDI, $\ln (X+1)$ & 5,090 & 1.84 & 0.00 & 3.14 & 0.00 & 14.00 \\
\hline Simple distance, $\ln (X)^{2}$ & 5,090 & 8.59 & 8.84 & 0.85 & 4.09 & 9.89 \\
\hline Weighted distance, all, $\ln (X)^{2,3}$ & 5,090 & 8.52 & 8.74 & 0.85 & 0.00 & 9.89 \\
\hline Weighted distance, USD, $\ln (X)^{2,4}$ & 5,090 & 8.54 & 8.75 & 0.83 & 4.10 & 9.89 \\
\hline Total lending, all, $(X)^{3}$ & 5,090 & $4,022.64$ & 19.51 & $29,432.10$ & 0.00 & $1,202,826.00$ \\
\hline Lending, USD, $(X)^{4}$ & 3,712 & $2,464.54$ & 29.85 & $25,249.75$ & 0.00 & $1,124,981.00$ \\
\hline Trade $(X)$ & 5,090 & $4,939.20$ & 243.09 & $25,450.35$ & 0.00 & $597,118.10$ \\
\hline Investment $(X)$ & 5,090 & $8,125.61$ & 11.54 & $56,072.84$ & 0.00 & $1,620,968.00$ \\
\hline $\mathrm{FDI}(\mathrm{X})$ & 5,090 & $2,853.85$ & 0.00 & $27,367.18$ & 0.00 & $1,196,809.00$ \\
\hline \multicolumn{7}{|l|}{ Advanced counterparties } \\
\hline Total lending, $\ln (X)$ & 1,071 & 5.67 & 6.13 & 3.89 & -6.91 & 14.00 \\
\hline USD lending, $\ln (X)$ & 942 & 4.50 & 5.04 & 3.86 & -6.91 & 13.93 \\
\hline Colony $(0 / 1)$ & 1,071 & 0.02 & 0.00 & 0.13 & 0.00 & 1.00 \\
\hline Common Language $(0 / 1)$ & 1,071 & 0.10 & 0.00 & 0.30 & 0.00 & 1.00 \\
\hline Trade, $\ln (X+1)$ & 1,071 & 7.24 & 7.32 & 2.37 & 0.00 & 13.22 \\
\hline Investment, $\ln (X+1)$ & 1,071 & 6.43 & 6.75 & 3.83 & 0.00 & 14.30 \\
\hline FDI, $\ln (X+1)$ & 1,071 & 4.80 & 5.53 & 4.01 & 0.00 & 13.51 \\
\hline Simple distance, $\ln (X)^{2}$ & 1,071 & 8.21 & 8.58 & 1.10 & 4.09 & 9.88 \\
\hline Weighted distance, all, $\ln (X)^{2,3}$ & 1,071 & 8.05 & 7.95 & 1.06 & 4.12 & 9.86 \\
\hline Weighted distance, USD, $\ln (X)^{2,4}$ & 1,071 & 8.13 & 8.09 & 1.02 & 4.10 & 9.86 \\
\hline Total lending, all, $(X)^{3}$ & 1,071 & $15,009.26$ & 458.88 & $60,998.79$ & 0.00 & $1,202,826.00$ \\
\hline Lending, USD, $(X)^{4}$ & 942 & $7,030.48$ & 153.71 & $48,996.32$ & 0.00 & $1,124,981.00$ \\
\hline Trade $(X)$ & 1,071 & $12,191.95$ & $1,505.36$ & $40,059.43$ & 0.00 & $549,720.30$ \\
\hline Investment $(X)$ & 1,071 & $33,328.48$ & 851.94 & $117,219.20$ & 0.00 & $1,620,968.00$ \\
\hline $\mathrm{FDI}(\mathrm{X})$ & 1,071 & $10,952.94$ & 252.34 & $45,752.88$ & 0.00 & $735,798.20$ \\
\hline \multicolumn{7}{|l|}{ EMDE counterparties } \\
\hline Total lending, $\ln (X)$ & 3,700 & 1.72 & 1.94 & 4.03 & -6.91 & 11.35 \\
\hline USD lending, $\ln (X)$ & 2,486 & 2.35 & 2.78 & 3.75 & -6.91 & 10.33 \\
\hline Colony $(0 / 1)$ & 3,700 & 0.03 & 0.00 & 0.16 & 0.00 & 1.00 \\
\hline Common Language $(0 / 1)$ & 3,700 & 0.14 & 0.00 & 0.34 & 0.00 & 1.00 \\
\hline Trade, $\ln (X+1)$ & 3,700 & 5.02 & 5.03 & 2.58 & 0.00 & 13.30 \\
\hline Investment, $\ln (X+1)$ & 3,700 & 2.48 & 0.89 & 2.96 & 0.00 & 12.71 \\
\hline FDI, $\ln (X+1)$ & 3,700 & 0.94 & 0.00 & 2.15 & 0.00 & 11.80 \\
\hline Simple distance, $\ln (X)^{2}$ & 3,700 & 8.68 & 8.86 & 0.73 & 4.93 & 9.89 \\
\hline Weighted distance, all, $\ln (X)^{2,3}$ & 3,700 & 8.63 & 8.78 & 0.73 & 0.00 & 9.89 \\
\hline Weighted distance, USD, $\ln (X)^{2,4}$ & 3,700 & 8.65 & 8.79 & 0.71 & 5.38 & 9.89 \\
\hline Total lending, all, $(X)^{3}$ & 3,700 & 707.81 & 6.99 & $3,219.59$ & 0.00 & $84,938.02$ \\
\hline Lending, USD, $(X)^{4}$ & 2,486 & 580.74 & 16.16 & $2,212.85$ & 0.00 & $30,624.81$ \\
\hline Trade $(X)$ & 3,700 & $2,973.91$ & 151.34 & $19,431.18$ & 0.00 & $597,118.10$ \\
\hline Investment $(X)$ & 3,700 & $1,268.85$ & 1.44 & $9,982.75$ & 0.00 & $332,224.50$ \\
\hline $\mathrm{FDI}(\mathrm{X})$ & 3,700 & 309.79 & 0.00 & $3,037.25$ & 0.00 & $133,079.90$ \\
\hline \multicolumn{7}{|c|}{$\begin{array}{l}1 \mathrm{X} \text { in USD millions; borrower countries relate to customers of BIS reporting banks; Annex Table } 2 \text { gives their precise definitions and } \\
\text { Table A3 lists the countries grouped into EMDEs and AEs, respectively. }\end{array}$} \\
\hline \multicolumn{7}{|c|}{2 Distance in $\mathrm{KM}$. } \\
\hline \multicolumn{7}{|c|}{3 Lending in all currencies to all sectors. } \\
\hline${ }^{4}$ Lending denominated in U.S. $\mathrm{d}$ & II sect & & & & & \\
\hline
\end{tabular}


Table 3. Cross-Border Lending, Distance and Other Types of Economic Interaction (Dependent Variable: Total lending in all currencies to all sectors (In))

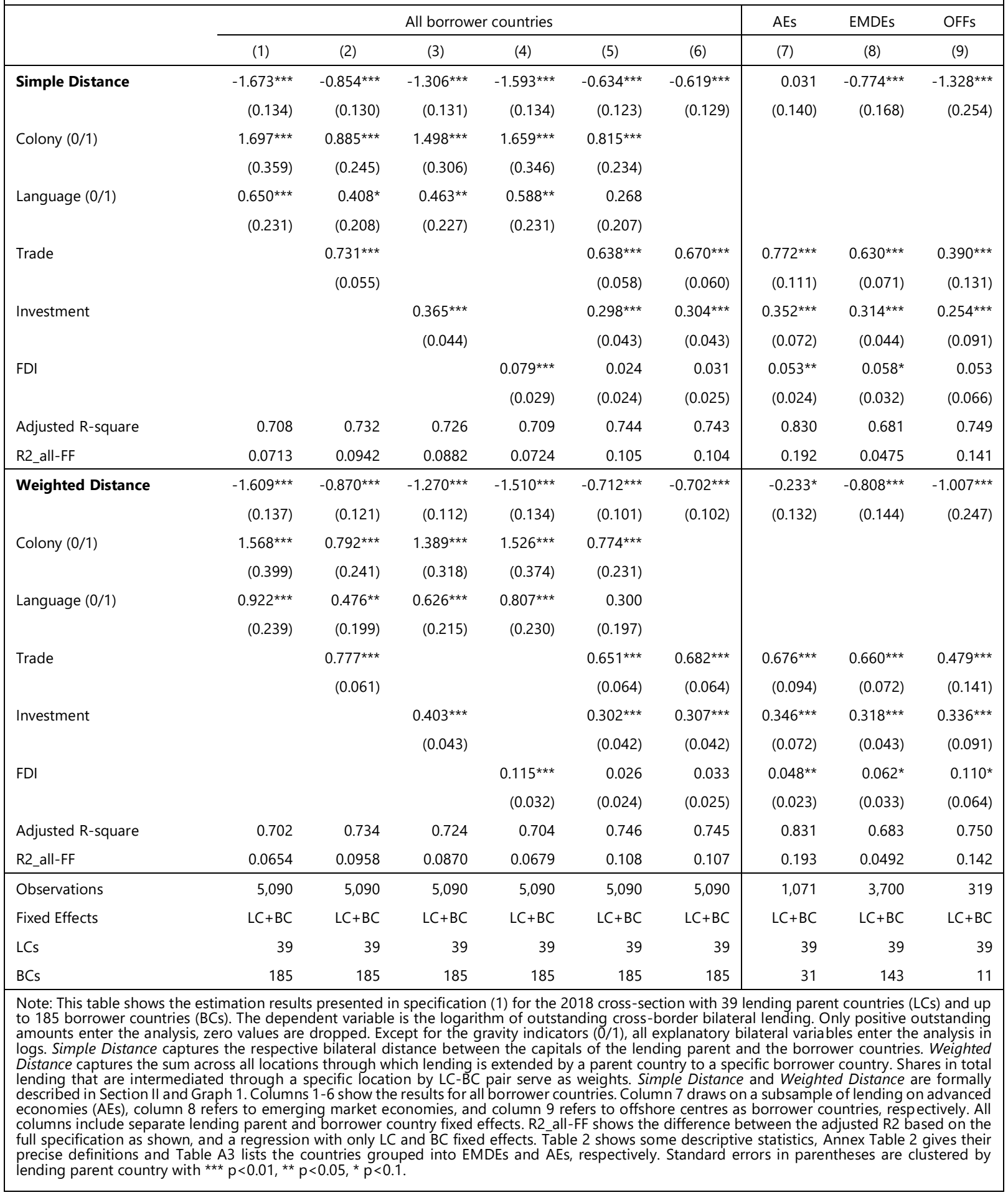


Table 4. Do Results Differ by Nationality of the Lending Bank?

(Dependent Variable: Total lending in all currencies to all sectors (In))

\begin{tabular}{|c|c|c|c|c|}
\hline & \multicolumn{2}{|c|}{ Borrower countries: Advanced } & \multicolumn{2}{|c|}{ Borrower countries: EMDEs } \\
\hline & $\begin{array}{c}\text { Simple } \\
\text { (1) }\end{array}$ & $\begin{array}{c}\text { Weighted } \\
\text { (2) }\end{array}$ & $\begin{array}{c}\text { Simple } \\
\text { (3) }\end{array}$ & $\begin{array}{c}\text { Weighted } \\
\text { (4) }\end{array}$ \\
\hline \multicolumn{5}{|l|}{ Standalone Variables } \\
\hline \multirow[t]{2}{*}{ Distance } & -0.203 & $-0.431^{\star *}$ & $-0.440^{*}$ & $-0.666^{* * *}$ \\
\hline & $(0.246)$ & $(0.183)$ & $(0.250)$ & $(0.192)$ \\
\hline \multirow[t]{2}{*}{ Trade } & $0.597^{\star \star *}$ & $0.567^{\star \star \star}$ & $0.504^{\star * \star}$ & $0.521^{* * *}$ \\
\hline & $(0.123)$ & $(0.108)$ & $(0.081)$ & $(0.084)$ \\
\hline \multirow[t]{2}{*}{ Investment } & $0.379 * * *$ & $0.371^{\star \star *}$ & $0.366^{\star * *}$ & $0.381^{* * *}$ \\
\hline & $(0.113)$ & $(0.107)$ & $(0.045)$ & $(0.047)$ \\
\hline \multirow[t]{2}{*}{ FDI } & $0.120^{\star *}$ & $0.112^{*}$ & $0.115^{\star *}$ & $0.108^{* *}$ \\
\hline & $(0.058)$ & $(0.056)$ & $(0.046)$ & $(0.043)$ \\
\hline \multicolumn{5}{|l|}{ Interaction Effects } \\
\hline \multirow[t]{2}{*}{$\operatorname{Dist}^{\star} \mathrm{CN}(0 / 1)$} & $1.221^{\star \star \star}$ & -0.083 & -0.207 & -0.065 \\
\hline & $(0.285)$ & $(0.204)$ & $(0.255)$ & $(0.200)$ \\
\hline \multirow[t]{2}{*}{ Dist*US(0/1) } & $0.641^{\star *}$ & $0.361^{* *}$ & -0.126 & -0.041 \\
\hline & $(0.249)$ & $(0.170)$ & $(0.345)$ & $(0.163)$ \\
\hline \multirow[t]{2}{*}{ Dist $^{*} \mathrm{JP}(0 / 1)$} & $-3.274^{* * *}$ & $3.109^{* * *}$ & -0.099 & $-0.801^{* * *}$ \\
\hline & $(0.956)$ & $(0.327)$ & $(0.254)$ & $(0.165)$ \\
\hline \multirow[t]{2}{*}{$\operatorname{Dist*} \mathrm{EU}(0 / 1)$} & 0.156 & 0.272 & -0.205 & 0.076 \\
\hline & $(0.251)$ & $(0.209)$ & $(0.252)$ & $(0.208)$ \\
\hline \multirow[t]{2}{*}{ DistEMDEexCN(0/1) } & -0.041 & -0.111 & $-1.076^{\star *}$ & $-0.699^{\star}$ \\
\hline & $(0.307)$ & $(0.246)$ & $(0.417)$ & $(0.358)$ \\
\hline \multirow[t]{2}{*}{ Trade* $\mathrm{CN}(0 / 1)$} & -0.097 & $-0.163^{*}$ & $0.452^{* \star \star}$ & $0.453^{* * *}$ \\
\hline & $(0.078)$ & $(0.084)$ & $(0.083)$ & $(0.083)$ \\
\hline \multirow[t]{2}{*}{ Trade*US(0/1) } & $-0.195^{\star \star}$ & $-0.299 * \star \star$ & $0.398^{\star \star \star}$ & $0.408^{* \star *}$ \\
\hline & $(0.084)$ & $(0.092)$ & $(0.066)$ & $(0.073)$ \\
\hline \multirow[t]{2}{*}{ Trade*JP(0/1) } & $-0.475^{* * *}$ & $-0.419 * * *$ & $0.228^{* *}$ & $0.176^{*}$ \\
\hline & $(0.078)$ & $(0.087)$ & $(0.087)$ & $(0.090)$ \\
\hline \multirow[t]{2}{*}{ Trade*EU(0/1) } & 0.041 & 0.031 & $0.189 * *$ & $0.226^{\star *}$ \\
\hline & $(0.100)$ & $(0.104)$ & $(0.093)$ & $(0.091)$ \\
\hline \multirow[t]{2}{*}{ Trade*EMDEexCN(0/1) } & 0.195 & 0.177 & 0.061 & 0.091 \\
\hline & $(0.157)$ & $(0.158)$ & $(0.108)$ & $(0.107)$ \\
\hline
\end{tabular}




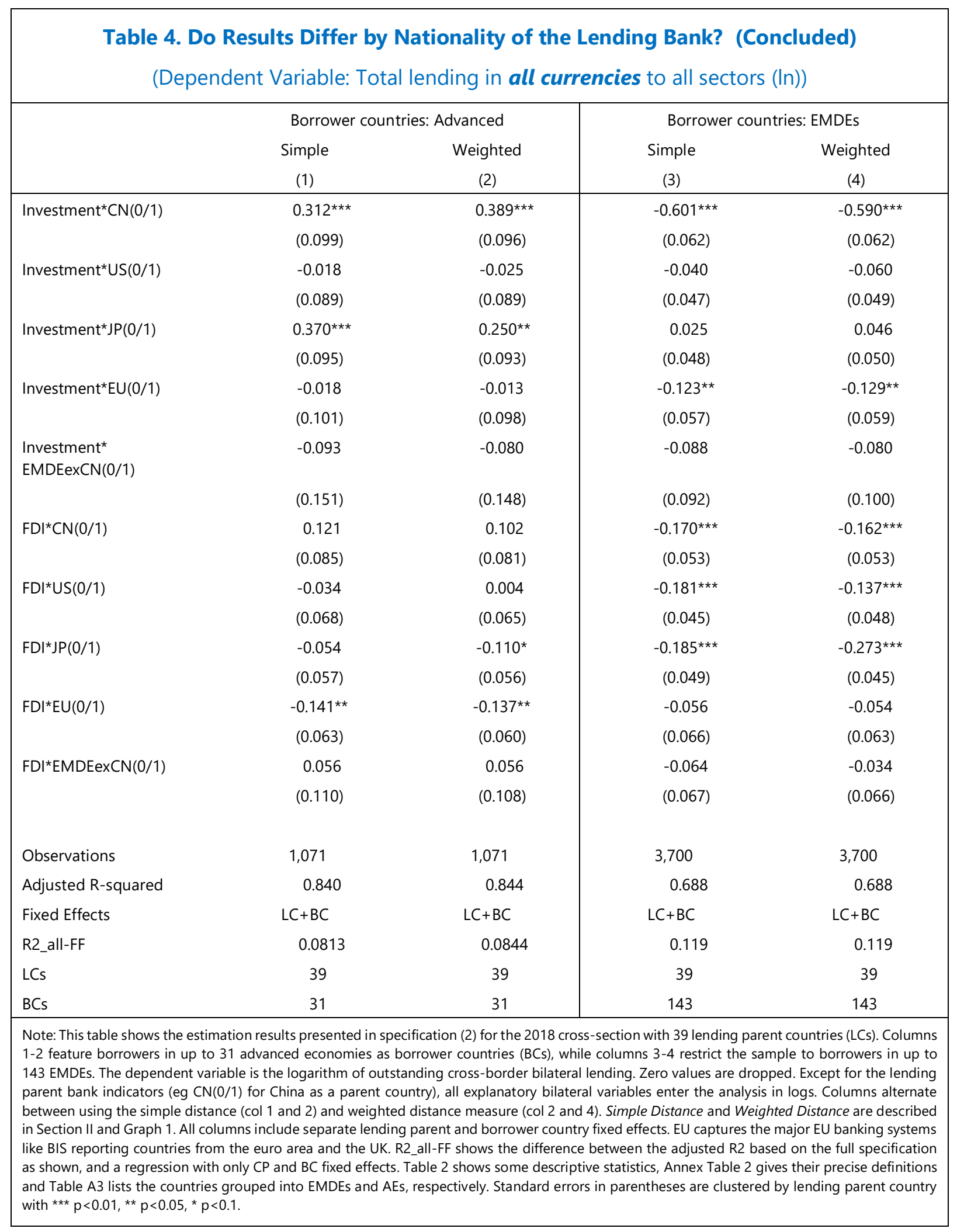

\section{CInternational Monetary Fund. Not for Redistribution}


Table 5. Do Results Differ by Nationality of the Lending Bank? U.S. Dollar Lending (Dependent Variable: Lending denominated in USD to all sectors (In))

\begin{tabular}{|c|c|c|c|c|}
\hline & \multicolumn{2}{|c|}{ Borrower countries: Advanced } & \multicolumn{2}{|c|}{ Borrower countries: EMDEs } \\
\hline & $\begin{array}{l}\text { Simple } \\
\text { (1) }\end{array}$ & $\begin{array}{c}\text { Weighted } \\
\text { (2) }\end{array}$ & $\begin{array}{c}\text { Simple } \\
(3) \\
\end{array}$ & $\begin{array}{c}\text { Weighted } \\
\text { (4) }\end{array}$ \\
\hline Standalone Variables & & & & \\
\hline Distance & $\begin{array}{l}-0.345 \\
(0.302)\end{array}$ & $\begin{array}{l}-0.144 \\
(0.209)\end{array}$ & $\begin{array}{l}-0.258 \\
(0.273)\end{array}$ & $\begin{array}{l}-0.418^{*} \\
(0.207)\end{array}$ \\
\hline Trade & $\begin{array}{l}0.416^{\star *} \\
(0.159)\end{array}$ & $\begin{array}{l}0.427^{\star \star \star} \\
(0.149)\end{array}$ & $\begin{array}{l}0.293^{* * *} \\
(0.089)\end{array}$ & $\begin{array}{c}0.297^{\star * *} \\
(0.086)\end{array}$ \\
\hline Investment & $\begin{array}{l}0.312^{* * *} \\
(0.106)\end{array}$ & $\begin{array}{l}0.298^{\star * *} \\
(0.101)\end{array}$ & $\begin{array}{l}0.390^{* * *} \\
(0.067)\end{array}$ & $\begin{array}{l}0.384^{* * *} \\
(0.067)\end{array}$ \\
\hline FDI & $\begin{array}{r}0.104 \\
(0.087)\end{array}$ & $\begin{array}{r}0.115 \\
(0.086)\end{array}$ & $\begin{array}{l}0.153^{* * *} \\
(0.047)\end{array}$ & $\begin{array}{l}0.147^{* * *} \\
(0.054)\end{array}$ \\
\hline Interaction Effects & & & & \\
\hline Dist $^{*} \mathrm{CN}(0 / 1)$ & $\begin{array}{l}1.019 * * * \\
(0.358)\end{array}$ & $\begin{array}{l}-0.081 \\
(0.251)\end{array}$ & $\begin{array}{c}-0.755^{\star *} \\
(0.332)\end{array}$ & $\begin{array}{c}-0.522^{\star *} \\
(0.198)\end{array}$ \\
\hline Dist*US(0/1) & $\begin{array}{l}0.956^{\text {*** }} \\
(0.295)\end{array}$ & $\begin{array}{l}0.576^{\star \star *} \\
(0.194)\end{array}$ & $\begin{array}{c}-0.757^{\star \star} \\
(0.349)\end{array}$ & $\begin{array}{l}-0.251 \\
(0.170)\end{array}$ \\
\hline Dist*JP(0/1) & $\begin{array}{c}-7.247^{\star \star \star} \\
(1.173)\end{array}$ & $\begin{array}{l}1.884^{\star \star \star} \\
(0.278)\end{array}$ & $\begin{array}{l}-0.150 \\
(0.342)\end{array}$ & $\begin{array}{c}-0.831^{\star * \star} \\
(0.210)\end{array}$ \\
\hline $\operatorname{Dist}^{\star} \mathrm{EU}(0 / 1)$ & $\begin{array}{l}0.539^{\star *} \\
(0.236)\end{array}$ & $\begin{array}{c}0.191 \\
(0.194)\end{array}$ & $\begin{array}{r}0.079 \\
(0.320)\end{array}$ & $\begin{array}{l}-0.067 \\
(0.233)\end{array}$ \\
\hline Dist*EMDEexCN(0/1) & $\begin{array}{l}-0.389 \\
(0.393)\end{array}$ & $\begin{array}{c}-0.607^{\star *} \\
(0.256)\end{array}$ & $\begin{array}{l}-0.597^{*} \\
(0.315)\end{array}$ & $\begin{array}{c}-0.448^{*} \\
(0.248)\end{array}$ \\
\hline Trade $^{\star} \mathrm{CN}(0 / 1)$ & $\begin{array}{c}-0.251^{\star \star} \\
(0.114)\end{array}$ & $\begin{array}{l}-0.312^{* *} \\
(0.120)\end{array}$ & $\begin{array}{l}0.876^{\star \star *} \\
(0.111)\end{array}$ & $\begin{array}{l}0.895^{\text {*** }} \\
(0.101)\end{array}$ \\
\hline Trade*US(0/1) & $\begin{array}{r}0.063 \\
(0.136)\end{array}$ & $\begin{array}{r}0.016 \\
(0.126)\end{array}$ & $\begin{array}{l}0.275^{\star * *} \\
(0.092)\end{array}$ & $\begin{array}{l}0.328^{\star * *} \\
(0.094)\end{array}$ \\
\hline Trade*JP(0/1) & $\begin{array}{c}-0.471^{\star \star \star} \\
(0.108)\end{array}$ & $\begin{array}{c}-0.372^{\star \star \star} \\
(0.105)\end{array}$ & $\begin{array}{l}0.458^{\star \star *} \\
(0.108)\end{array}$ & $\begin{array}{l}0.339 * * * \\
(0.104)\end{array}$ \\
\hline Trade*EU(0/1) & $\begin{array}{l}-0.049 \\
(0.127)\end{array}$ & $\begin{array}{l}-0.115 \\
(0.131)\end{array}$ & $\begin{array}{l}0.178^{*} \\
(0.095)\end{array}$ & $\begin{array}{r}0.153 \\
(0.093)\end{array}$ \\
\hline Trade*EMDEexCN(0/1) & $\begin{array}{r}0.255 \\
(0.166)\end{array}$ & $\begin{array}{r}0.229 \\
(0.167)\end{array}$ & $\begin{array}{r}0.152 \\
(0.139)\end{array}$ & $\begin{array}{r}0.155 \\
(0.137)\end{array}$ \\
\hline
\end{tabular}


Table 5. Do Results Differ by Nationality of the Lending Bank? U.S. Dollar Lending (Concluded)

(Dependent Variable: Lending denominated in USD to all sectors (In))

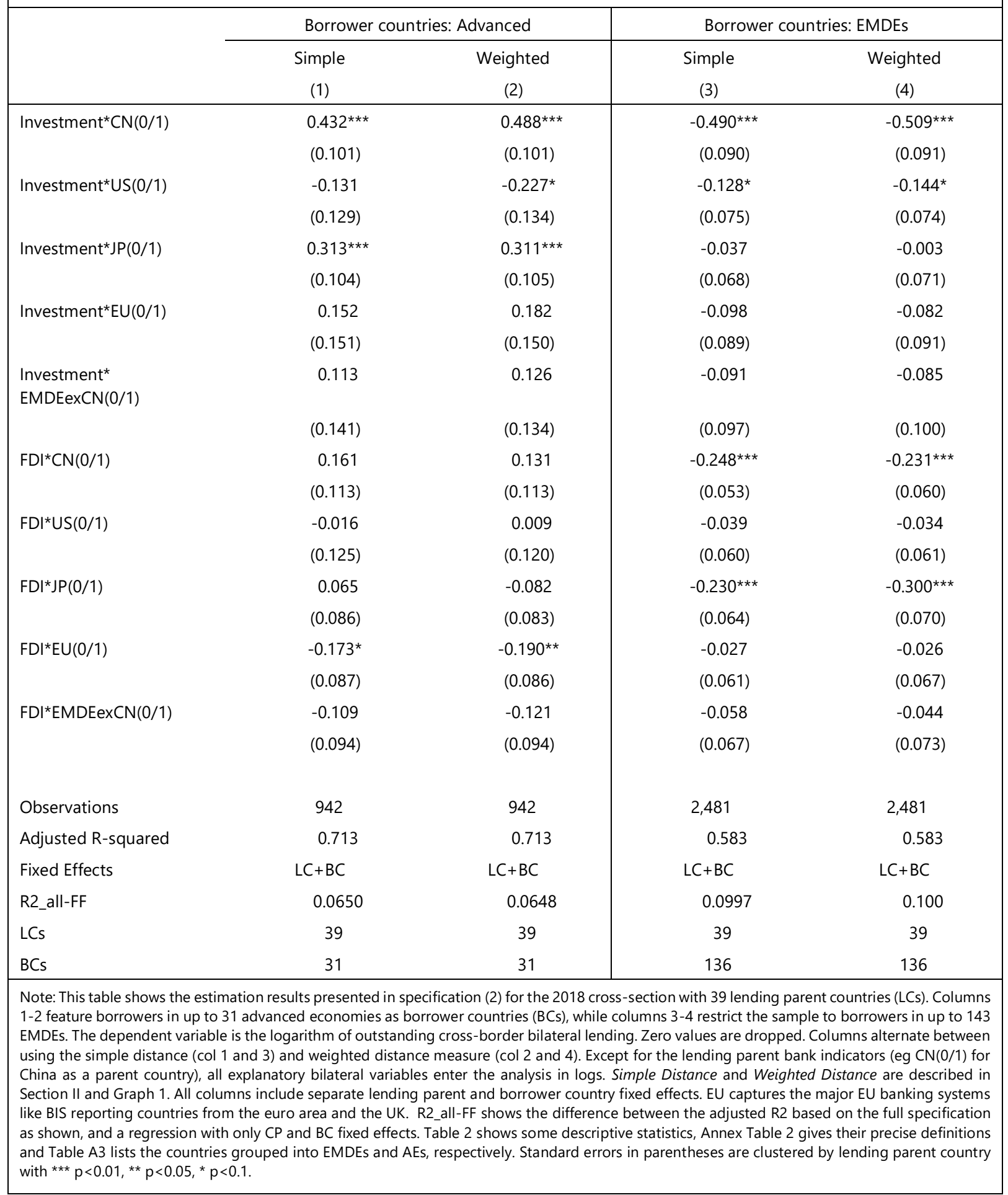

CInternational Monetary Fund. Not for Redistribution 


\begin{tabular}{|c|c|c|c|c|c|c|c|c|}
\hline \multicolumn{9}{|c|}{$\begin{array}{l}\text { Table 6. Zooming in on Chinese Banks } \\
\text { t Variable: Total lending in all currencies (In), all control variables) }\end{array}$} \\
\hline \multirow{3}{*}{ Variables } & \multicolumn{4}{|c|}{ X=BRI 2015} & \multicolumn{4}{|c|}{ X=Swap line } \\
\hline & \multicolumn{2}{|c|}{ Simple distance } & \multicolumn{2}{|c|}{ Weighted distance } & \multicolumn{2}{|c|}{ Simple distance } & \multicolumn{2}{|c|}{ Weighted distance } \\
\hline & $(1)$ & $(2)$ & $(3)$ & $(4)$ & $(5)$ & $(6)$ & $(7)$ & $(8)$ \\
\hline \multicolumn{9}{|c|}{ Standalone Variables } \\
\hline \multirow[t]{2}{*}{ Distance } & -0.524 & -0.337 & -0.600 & -0.432 & -0.200 & -0.210 & -0.280 & -0.345 \\
\hline & $(0.472)$ & $(0.665)$ & $(0.498)$ & $(0.755)$ & $(0.381)$ & $(0.593)$ & $(0.382)$ & $(0.547)$ \\
\hline \multirow[t]{2}{*}{$x$} & -0.302 & 3.590 & -0.363 & 2.585 & $1.359^{\star}$ & 0.437 & $1.360^{*}$ & -0.942 \\
\hline & $(0.649)$ & $(10.688)$ & $(0.674)$ & $(10.532)$ & $(0.720)$ & $(7.583)$ & $(0.715)$ & $(7.419)$ \\
\hline \multirow[t]{2}{*}{ Trade } & $0.935^{\star \star \star}$ & $0.922^{* * *}$ & $0.936^{\star \star *}$ & $0.920^{\star * *}$ & $0.932^{* * *}$ & $0.952^{* * *}$ & $0.928^{\star * \star}$ & $0.946^{* * *}$ \\
\hline & $(0.190)$ & $(0.248)$ & $(0.189)$ & $(0.248)$ & $(0.190)$ & $(0.208)$ & (0.189) & $(0.207)$ \\
\hline \multirow[t]{2}{*}{ Investment } & -0.038 & -0.037 & -0.042 & -0.034 & -0.150 & -0.217 & -0.149 & -0.213 \\
\hline & $(0.185)$ & $(0.338)$ & $(0.184)$ & $(0.336)$ & $(0.206)$ & $(0.237)$ & $(0.203)$ & $(0.231)$ \\
\hline \multirow[t]{2}{*}{ FDI } & 0.032 & 0.047 & 0.031 & 0.043 & 0.042 & 0.027 & 0.037 & 0.016 \\
\hline & $(0.133)$ & $(0.223)$ & $(0.131)$ & $(0.219)$ & $(0.134)$ & $(0.157)$ & $(0.132)$ & $(0.154)$ \\
\hline \multicolumn{9}{|c|}{ Interaction Effects } \\
\hline \multirow[t]{2}{*}{$X^{\star}$ Distance } & & -0.460 & & -0.357 & & 0.103 & & 0.249 \\
\hline & & $(1.060)$ & & $(1.057)$ & & $(0.693)$ & & $(0.680)$ \\
\hline \multirow[t]{2}{*}{$X *$ Trade } & & 0.032 & & 0.043 & & -0.163 & & -0.156 \\
\hline & & $(0.441)$ & & $(0.433)$ & & $(0.556)$ & & $(0.556)$ \\
\hline \multirow[t]{2}{*}{$X^{*} \mathrm{FDI}$} & & -0.018 & & -0.021 & & 0.002 & & 0.015 \\
\hline & & $(0.293)$ & & $(0.287)$ & & $(0.322)$ & & $(0.320)$ \\
\hline \multirow[t]{2}{*}{$X^{\star}$ Investment } & & -0.011 & & -0.025 & & 0.370 & & 0.365 \\
\hline & & $(0.391)$ & & $(0.388)$ & & $(0.434)$ & & $(0.431)$ \\
\hline \multirow[t]{2}{*}{ Constant } & 3.233 & 1.554 & 3.929 & 2.442 & 0.208 & 0.290 & 0.960 & 1.562 \\
\hline & $(4.848)$ & (6.794) & $(5.019)$ & (7.549) & (3.995) & (6.042) & (3.968) & (5.578) \\
\hline Observations & 137 & 137 & 137 & 137 & 137 & 137 & 137 & 137 \\
\hline R-squared & 0.354 & 0.355 & 0.355 & 0.356 & 0.368 & 0.372 & 0.368 & 0.373 \\
\hline \multicolumn{9}{|c|}{$\begin{array}{l}\text { Note: This table restricts the estimation sample to the } 2018 \text { cross-section of Chinese lending parent banks and all EMDE borrower countries (BCs). } \\
\text { To evaluate the effects of bilateral initiatives like the BRI (" } \mathrm{X} \text { " in col } 1-4 \text { ) and swap-lines (" } \mathrm{X} \text { " in col } 5-8 \text { ), it interacts the covariates with indicators of } \\
\text { whether the borrower countries take part in the respective initiate. The dependent variable is the logarithm of outstanding bilateral cross-border } \\
\text { lending. Except for the indicators } X \text {, all explanatory variables enter our analysis in log. Annex Table } 2 \text { gives their precise definitions and Table A3 lists } \\
\text { the countries grouped into EMDEs and AEs, respectively. Standard errors in parentheses are robust. }{ }^{* * *} p<0.01,{ }^{* *} p<0.05,{ }^{*} p<0.1 \text {. }\end{array}$} \\
\hline
\end{tabular}

CInternational Monetary Fund. Not for Redistribution 


\begin{tabular}{|c|c|c|c|c|c|c|c|c|}
\hline \multirow{3}{*}{ Variables } & \multicolumn{4}{|c|}{ PPML } & \multicolumn{4}{|c|}{ Keep Zeros with $\ln (Y+1)$} \\
\hline & \multicolumn{2}{|c|}{ AEs } & \multicolumn{2}{|c|}{ EMDEs } & \multicolumn{2}{|c|}{ AEs } & \multicolumn{2}{|c|}{ EMDEs } \\
\hline & $\begin{array}{c}\text { Simple } \\
\text { distance } \\
(1)\end{array}$ & $\begin{array}{c}\text { Weighted } \\
\text { distance } \\
\text { (2) }\end{array}$ & $\begin{array}{c}\text { Simple } \\
\text { distance } \\
\text { (3) }\end{array}$ & $\begin{array}{c}\text { Weighted } \\
\text { distance } \\
(4)\end{array}$ & $\begin{array}{c}\text { Simple } \\
\text { distance } \\
\text { (5) }\end{array}$ & $\begin{array}{c}\text { Weighted } \\
\text { distance } \\
(6)\end{array}$ & $\begin{array}{c}\text { Simple } \\
\text { distance } \\
\text { (7) }\end{array}$ & $\begin{array}{c}\text { Weighted } \\
\text { distance } \\
\text { (8) }\end{array}$ \\
\hline Standalone Variables & & & & & & & & \\
\hline Distance & $\begin{array}{r}0.130 \\
(0.159)\end{array}$ & $\begin{array}{l}-0.017 \\
(0.215)\end{array}$ & $\begin{array}{l}-0.087 \\
(0.207)\end{array}$ & $\begin{array}{r}-0.352^{\star *} \\
(0.170)\end{array}$ & $\begin{array}{r}-0.365 \\
(0.242)\end{array}$ & $\begin{array}{l}-0.212 \\
(0.181)\end{array}$ & $\begin{array}{l}-0.152 \\
(0.134)\end{array}$ & $\begin{array}{l}-0.205^{*} \\
(0.115)\end{array}$ \\
\hline Trade & $\begin{array}{c}0.574^{* * *} \\
(0.125)\end{array}$ & $\begin{array}{c}0.468^{* * *} \\
(0.118)\end{array}$ & $\begin{array}{r}0.304^{* * *} \\
(0.101)\end{array}$ & $\begin{array}{r}0.275^{* * *} \\
(0.103)\end{array}$ & $\begin{array}{c}0.298^{* *} \\
(0.112)\end{array}$ & $\begin{array}{r}0.312^{* * *} \\
(0.115)\end{array}$ & $\begin{array}{r}0.273^{* * *} \\
(0.047)\end{array}$ & $\begin{array}{r}0.271^{\star * *} \\
(0.046)\end{array}$ \\
\hline Investment & $\begin{array}{r}0.343^{* * *} \\
(0.083)\end{array}$ & $\begin{array}{c}0.340^{* * *} \\
(0.087)\end{array}$ & $\begin{array}{r}0.367^{* * *} \\
(0.054)\end{array}$ & $\begin{array}{r}0.367^{* * *} \\
(0.058)\end{array}$ & $\begin{array}{r}0.341^{* * *} \\
(0.084)\end{array}$ & $\begin{array}{r}0.331^{* * *} \\
(0.080)\end{array}$ & $\begin{array}{r}0.325^{* * *} \\
(0.050)\end{array}$ & $\begin{array}{r}0.329^{* * *} \\
(0.051)\end{array}$ \\
\hline FDI & $\begin{array}{r}0.034 \\
(0.039)\end{array}$ & $\begin{array}{r}0.036 \\
(0.041)\end{array}$ & $\begin{array}{l}0.109 * * \\
(0.053)\end{array}$ & $\begin{array}{l}0.104^{* *} \\
(0.049)\end{array}$ & $\begin{array}{l}0.167^{\star *} \\
(0.070)\end{array}$ & $\begin{array}{l}0.174^{\star *} \\
(0.068)\end{array}$ & $\begin{array}{c}0.171^{\star * *} \\
(0.052)\end{array}$ & $\begin{array}{r}0.167^{\star \star *} \\
(0.053)\end{array}$ \\
\hline Interaction Effects & & & & & & & & \\
\hline $\operatorname{Dist}^{\star} \mathrm{CN}(0 / 1)$ & $\begin{array}{l}-0.089 \\
(0.255)\end{array}$ & $\begin{array}{r}0.347 \\
(0.286)\end{array}$ & $\begin{array}{l}-0.216 \\
(0.218)\end{array}$ & $\begin{array}{r}0.005 \\
(0.175)\end{array}$ & $\begin{array}{r}0.993^{\star * \star} \\
(0.274)\end{array}$ & $\begin{array}{l}0.178^{* *} \\
(0.085)\end{array}$ & $\begin{array}{r}-0.322^{* *} \\
(0.133)\end{array}$ & $\begin{array}{r}-0.303^{* *} \\
(0.116)\end{array}$ \\
\hline Dist*US(0/1) & $\begin{array}{r}0.157 \\
(0.164)\end{array}$ & $\begin{array}{l}-0.002 \\
(0.184)\end{array}$ & $\begin{array}{r}0.163 \\
(0.335)\end{array}$ & $\begin{array}{r}0.151 \\
(0.193)\end{array}$ & $\begin{array}{c}0.714^{\star * *} \\
(0.261)\end{array}$ & $\begin{array}{l}-0.060 \\
(0.073)\end{array}$ & $\begin{array}{l}-0.063 \\
(0.173)\end{array}$ & $\begin{array}{r}-0.203^{\star * *} \\
(0.055)\end{array}$ \\
\hline Dist*JP(0/1) & $\begin{array}{l}1.003^{*} \\
(0.565)\end{array}$ & $\begin{array}{r}-0.332 \\
(0.455)\end{array}$ & $\begin{array}{r}0.210 \\
(0.208)\end{array}$ & $\begin{array}{l}0.267^{*} \\
(0.150)\end{array}$ & $\begin{array}{r}-2.359^{* * *} \\
(0.728)\end{array}$ & $\begin{array}{r}1.908^{* * *} \\
(0.183)\end{array}$ & $\begin{array}{r}0.055 \\
(0.139)\end{array}$ & $\begin{array}{r}-0.678^{\star * *} \\
(0.068)\end{array}$ \\
\hline $\operatorname{Dist*} E U(0 / 1)$ & $\begin{array}{r}0.080 \\
(0.151)\end{array}$ & $\begin{array}{r}0.146 \\
(0.219)\end{array}$ & $\begin{array}{l}-0.175 \\
(0.233)\end{array}$ & $\begin{array}{l}-0.149 \\
(0.196)\end{array}$ & $\begin{array}{r}0.193 \\
(0.249)\end{array}$ & $\begin{array}{r}0.031 \\
(0.196)\end{array}$ & $\begin{array}{l}-0.113 \\
(0.178)\end{array}$ & $\begin{array}{l}-0.064 \\
(0.119)\end{array}$ \\
\hline Dist*EMDEexCN(0/1) & $\begin{array}{r}0.234 \\
(0.239)\end{array}$ & $\begin{array}{r}0.344 \\
(0.240)\end{array}$ & $\begin{array}{l}-0.345 \\
(0.320)\end{array}$ & $\begin{array}{l}-0.050 \\
(0.261)\end{array}$ & $\begin{array}{r}0.005 \\
(0.281)\end{array}$ & $\begin{array}{r}-0.390^{\star *} \\
(0.145)\end{array}$ & $\begin{array}{r}-0.575^{\star \star \star} \\
(0.188)\end{array}$ & $\begin{array}{r}-0.486^{\star * *} \\
(0.176)\end{array}$ \\
\hline Trade ${ }^{\star} \mathrm{CN}(0 / 1)$ & $\begin{array}{l}-0.125 \\
(0.088)\end{array}$ & $\begin{array}{l}-0.131 \\
(0.089)\end{array}$ & $\begin{array}{l}0.166^{*} \\
(0.096)\end{array}$ & $\begin{array}{l}0.169 * \\
(0.099)\end{array}$ & $\begin{array}{r}0.017 \\
(0.075)\end{array}$ & $\begin{array}{r}0.009 \\
(0.079)\end{array}$ & $\begin{array}{r}0.551^{\star * *} \\
(0.045)\end{array}$ & $\begin{array}{r}0.553^{\star * *} \\
(0.044)\end{array}$ \\
\hline Trade*US(0/1) & $\begin{array}{r}-0.337^{\star *} \\
(0.135)\end{array}$ & $\begin{array}{r}-0.437^{\star \star \star} \\
(0.146)\end{array}$ & $\begin{array}{r}0.050 \\
(0.087)\end{array}$ & $\begin{array}{r}0.052 \\
(0.098)\end{array}$ & $\begin{array}{l}-0.094 \\
(0.077)\end{array}$ & $\begin{array}{r}-0.212^{\star *} \\
(0.091)\end{array}$ & $\begin{array}{c}0.263^{* * *} \\
(0.040)\end{array}$ & $\begin{array}{r}0.245^{\star * *} \\
(0.039)\end{array}$ \\
\hline Trade*JP(0/1) & $\begin{array}{r}-0.291^{* * *} \\
(0.076)\end{array}$ & $\begin{array}{r}-0.306^{\star * *} \\
(0.086)\end{array}$ & $\begin{array}{r}0.080 \\
(0.094)\end{array}$ & $\begin{array}{r}0.047 \\
(0.095)\end{array}$ & $\begin{array}{r}-0.279^{* * *} \\
(0.080)\end{array}$ & $\begin{array}{l}-0.109 \\
(0.081)\end{array}$ & $\begin{array}{r}0.378^{\star * *} \\
(0.048)\end{array}$ & $\begin{array}{r}0.311^{\star * *} \\
(0.046)\end{array}$ \\
\hline Trade*EU(0/1) & $\begin{array}{r}0.051 \\
(0.071)\end{array}$ & $\begin{array}{r}0.050 \\
(0.076)\end{array}$ & $\begin{array}{r}0.071 \\
(0.104)\end{array}$ & $\begin{array}{r}0.060 \\
(0.104)\end{array}$ & $\begin{array}{r}0.122 \\
(0.098)\end{array}$ & $\begin{array}{r}0.109 \\
(0.101)\end{array}$ & $\begin{array}{c}0.178^{* *} \\
(0.078)\end{array}$ & $\begin{array}{r}0.185^{\star *} \\
(0.072)\end{array}$ \\
\hline Trade*EMDEexCN(0/1) & $\begin{array}{r}-0.282^{* * *} \\
(0.106)\end{array}$ & $\begin{array}{c}-0.269 * * \\
(0.107)\end{array}$ & $\begin{array}{r}0.089 \\
(0.137)\end{array}$ & $\begin{array}{r}0.114 \\
(0.143)\end{array}$ & $\begin{array}{r}0.110 \\
(0.101)\end{array}$ & $\begin{array}{r}0.098 \\
(0.102)\end{array}$ & $\begin{array}{l}-0.060 \\
(0.058)\end{array}$ & $\begin{array}{l}-0.054 \\
(0.058)\end{array}$ \\
\hline
\end{tabular}


Table 7. Alternative Estimation Method: PPML (Concluded)

(Dependent Variable: Total lending in all currencies (In) to all sectors)

\begin{tabular}{|c|c|c|c|c|c|c|c|c|}
\hline \multirow{3}{*}{ Variables } & \multicolumn{4}{|c|}{ PPML } & \multicolumn{4}{|c|}{ Keep Zeros with $\ln (\mathrm{Y}+1)$} \\
\hline & \multicolumn{2}{|c|}{ AEs } & \multicolumn{2}{|c|}{ EMDEs } & \multicolumn{2}{|c|}{ AEs } & \multicolumn{2}{|c|}{ EMDEs } \\
\hline & $\begin{array}{c}\text { Simple } \\
\text { distance } \\
(1)\end{array}$ & $\begin{array}{c}\text { Weighted } \\
\text { distance } \\
\text { (2) }\end{array}$ & $\begin{array}{c}\text { Simple } \\
\text { distance } \\
\text { (3) }\end{array}$ & $\begin{array}{c}\text { Weighted } \\
\text { distance } \\
\text { (4) }\end{array}$ & $\begin{array}{c}\text { Simple } \\
\text { distance } \\
(5)\end{array}$ & $\begin{array}{c}\text { Weighted } \\
\text { distance } \\
\text { (6) }\end{array}$ & $\begin{array}{c}\text { Simple } \\
\text { distance } \\
(7)\end{array}$ & $\begin{array}{c}\text { Weighted } \\
\text { distance } \\
\text { (8) }\end{array}$ \\
\hline \multirow[t]{2}{*}{ Investment ${ }^{\star} \mathrm{CN}(0 / 1)$} & 0.109 & 0.021 & $-0.135^{\star \star \star}$ & $-0.143^{\star \star *}$ & $0.209 * * *$ & $0.240 * * *$ & $-0.340^{* * *}$ & $-0.342^{\star \star *}$ \\
\hline & $(0.073)$ & $(0.062)$ & $(0.044)$ & $(0.053)$ & $(0.076)$ & $(0.071)$ & $(0.051)$ & $(0.051)$ \\
\hline \multirow[t]{2}{*}{ Investment*US(0/1) } & -0.080 & -0.045 & -0.050 & -0.035 & $0.306^{* * *}$ & $0.359 * * *$ & 0.008 & 0.003 \\
\hline & $(0.165)$ & $(0.210)$ & $(0.062)$ & $(0.071)$ & $(0.072)$ & $(0.068)$ & $(0.052)$ & $(0.053)$ \\
\hline \multirow[t]{2}{*}{ Investment*JP(0/1) } & $0.295^{* * *}$ & $0.398^{* * *}$ & $0.212^{* * *}$ & $0.224^{\star * *}$ & $0.531^{* * *}$ & $0.422^{* * *}$ & $0.172^{\star * \star}$ & $0.199^{\star \star *}$ \\
\hline & $(0.088)$ & $(0.103)$ & $(0.061)$ & $(0.068)$ & $(0.072)$ & $(0.074)$ & $(0.046)$ & $(0.049)$ \\
\hline \multirow[t]{2}{*}{ Investment* $\mathrm{EU}(0 / 1)$} & 0.060 & 0.079 & 0.065 & 0.060 & 0.104 & 0.115 & -0.056 & -0.058 \\
\hline & $(0.055)$ & $(0.050)$ & $(0.051)$ & $(0.057)$ & $(0.080)$ & $(0.079)$ & $(0.092)$ & $(0.093)$ \\
\hline \multirow{2}{*}{$\begin{array}{l}\text { Investment }{ }^{\star} \\
\text { EMDEexCN }(0 / 1)\end{array}$} & $-0.112^{*}$ & $-0.109^{*}$ & -0.116 & -0.115 & -0.072 & -0.058 & 0.111 & 0.112 \\
\hline & $(0065)$ & $(0063)$ & $(0099)$ & $(0.105)$ & & $(0105)$ & () (207) & $(0074)$ \\
\hline \multirow[t]{2}{*}{$\mathrm{FDI}{ }^{*} \mathrm{CN}(0 / 1)$} & -0.053 & -0.001 & $-0.222^{* * *}$ & $-0.215^{\star \star \star}$ & 0.026 & -0.006 & $-0.166^{\star \star \star}$ & $-0.161^{\star * *}$ \\
\hline & $(0.079)$ & $(0.065)$ & $(0.064)$ & $(0.061)$ & $(0.077)$ & $(0.073)$ & $(0.047)$ & $(0.049)$ \\
\hline \multirow[t]{2}{*}{$\mathrm{FDI} \cup \mathrm{US}(0 / 1)$} & $0.380^{* *}$ & $0.454^{\star *}$ & -0.038 & -0.038 & $-0.143^{*}$ & $-0.144^{\star *}$ & -0.027 & -0.003 \\
\hline & $(0.174)$ & $(0.213)$ & $(0.057)$ & $(0.056)$ & $(0.071)$ & $(0.068)$ & $(0.051)$ & $(0.054)$ \\
\hline \multirow[t]{2}{*}{$\mathrm{FDI} * \mathrm{JP}(0 / 1)$} & -0.023 & -0.021 & $-0.131^{\star *}$ & $-0.160^{\star * *}$ & $-0.160^{\star *}$ & $-0.237^{* * *}$ & $-0.161^{* * *}$ & $-0.244^{\star * *}$ \\
\hline & $(0.052)$ & $(0.058)$ & $(0.061)$ & $(0.062)$ & $(0.067)$ & $(0.067)$ & $(0.051)$ & $(0.058)$ \\
\hline \multirow[t]{2}{*}{$\mathrm{FDI}{ }^{\star} \mathrm{EU}(0 / 1)$} & -0.038 & -0.041 & -0.048 & -0.048 & $-0.168^{* *}$ & $-0.175^{\star *}$ & 0.000 & 0.005 \\
\hline & $(0.042)$ & $(0.044)$ & $(0.056)$ & $(0.053)$ & $(0.070)$ & $(0.069)$ & $(0.068)$ & $(0.069)$ \\
\hline \multirow[t]{2}{*}{$\mathrm{FDI}{ }^{*} \mathrm{EMDEexCN}(0 / 1)$} & $0.287^{\star \star}$ & $0.285^{\star \star}$ & -0.047 & -0.041 & -0.030 & -0.044 & -0.065 & -0.056 \\
\hline & $(0.126)$ & $(0.120)$ & $(0.075)$ & $(0.076)$ & $(0.083)$ & $(0.080)$ & $(0.071)$ & $(0.074)$ \\
\hline Observations & 1,187 & 1,187 & 5,565 & 5,565 & 1,187 & 1,187 & 5,565 & 5,565 \\
\hline R-squared & 0.958 & 0.956 & 0.819 & 0.832 & & & & \\
\hline Fixed Effects & $L C+B C$ & $L C+B C$ & $L C+B C$ & $L C+B C$ & $L C+B C$ & $L C+B C$ & $L C+B C$ & $\mathrm{LC}+\mathrm{BC}$ \\
\hline R2_all-FF & & & & & 0.0719 & 0.0729 & 0.152 & 0.152 \\
\hline LCs & 39 & 39 & 39 & 39 & 39 & 39 & 39 & 39 \\
\hline $\mathrm{BCs}$ & 31 & 31 & 143 & 143 & 31 & 31 & 143 & 143 \\
\hline \multicolumn{9}{|c|}{ 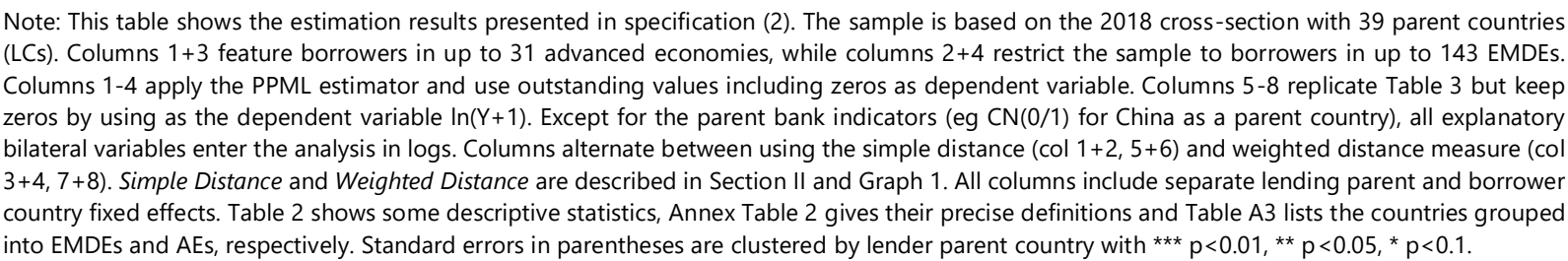 } \\
\hline
\end{tabular}


Annex Table 1. Cross-Border Banking, Trade and Investments: China Compared with Other Major Players in Advance Economies (AEs) and EMDEs

\begin{tabular}{|c|c|c|c|c|c|c|c|c|c|}
\hline Positions & Type of measures & $\mathrm{CN}$ & $J P$ & $\mathrm{FR}$ & GB & US & $\mathrm{DE}$ & ES & $\mathrm{CH}$ \\
\hline \multirow{5}{*}{$\begin{array}{l}\text { Total bank } \\
\text { lending } \\
\text { (2018Q2) }\end{array}$} & Share in global lending & & & & & & & & \\
\hline & -Among AE borrowers & 2.4 & 14.8 & 13.6 & 10.4 & 11.1 & 10.3 & 3.0 & 5.8 \\
\hline & -Among EMDE borrowers & 23.7 & 11.2 & 8.1 & 7.8 & 7.1 & 5.1 & 3.1 & 3.1 \\
\hline & -Among OFC borrowers & 13.7 & 24.3 & 5.6 & 4.9 & 13.4 & 6.0 & 0.8 & 11.4 \\
\hline & Top lender (\# countries) & & & & & & & & \\
\hline \multirow{11}{*}{$\begin{array}{l}\text { USD-deno. } \\
\text { bank lending } \\
\text { (2018Q2) }\end{array}$} & -Among AE borrowers & 0 & 3 & 6 & 0 & 1 & 4 & 2 & 1 \\
\hline & -Among EMDE borrowers & 63 & 6 & 10 & 5 & 9 & 5 & 2 & 4 \\
\hline & -Among OFC borrowers & 3 & 2 & 0 & 0 & 1 & 0 & 0 & 2 \\
\hline & Share in global lending & & & & & & & & \\
\hline & -Among AE borrowers & 3.8 & 20.2 & 8.7 & 9.4 & 14.9 & 7.4 & 1.9 & 7.8 \\
\hline & -Among EMDE borrowers & 27.2 & 10.6 & 6.4 & 7.8 & 9.2 & 3.5 & 2.8 & 2.9 \\
\hline & -Among OFC borrowers & 13.0 & 16.3 & 6.1 & 4.2 & 17.6 & 6.5 & 0.9 & 13.7 \\
\hline & Top lender (\# countries) & & & & & & & & \\
\hline & -Among AE borrowers & 0 & 4 & 4 & 2 & 2 & 3 & 1 & 2 \\
\hline & -Among EMDE borrowers & 55 & 9 & 8 & 6 & 14 & 4 & 1 & 6 \\
\hline & -Among OFC borrowers & 3 & 3 & 1 & 1 & 3 & 0 & 0 & 4 \\
\hline \multirow{8}{*}{$\begin{array}{l}\text { Imports } \\
\text { (End 2016) }\end{array}$} & Share in global imports & & & & & & & & \\
\hline & -Among AE borrowers & 9.6 & 3.0 & 5.8 & 6.9 & 13.7 & 9.8 & 2.8 & 2.7 \\
\hline & -Among EMDE borrowers & 12.9 & 6.5 & 2.7 & 2.9 & 21.7 & 6.8 & 1.9 & 1.3 \\
\hline & -Among OFC borrowers & 15.9 & 3.8 & 1.4 & 3.7 & 10.3 & 3.1 & 0.3 & 4.5 \\
\hline & Top partner (\# countries) & & & & & & & & \\
\hline & -Among AE borrowers & 3 & 0 & 1 & 2 & 5 & 13 & 1 & 1 \\
\hline & -Among EMDE borrowers & 41 & 5 & 5 & 1 & 32 & 8 & 3 & 6 \\
\hline & -Among OFC borrowers & 1 & 1 & 0 & 0 & 7 & 2 & 0 & 1 \\
\hline \multirow{8}{*}{$\begin{array}{l}\text { Exports } \\
\text { (End 2016) }\end{array}$} & Share in global exports & & & & & & & & \\
\hline & -Among AE borrowers & 13.0 & 3.3 & 4.9 & 4.2 & 9.4 & 12.5 & 2.8 & 2.8 \\
\hline & -Among EMDE borrowers & 16.3 & 6.8 & 2.5 & 2.0 & 13.9 & 8.8 & 1.4 & 1.6 \\
\hline & -Among OFC borrowers & 39.1 & 7.1 & 1.7 & 1.9 & 8.5 & 2.1 & 0.3 & 3.0 \\
\hline & Top partner (\# countries) & & & & & & & & \\
\hline & -Among AE borrowers & 3 & 0 & 0 & 2 & 1 & 16 & 1 & 0 \\
\hline & -Among EMDE borrowers & 56 & 1 & 8 & 0 & 28 & 11 & 2 & 0 \\
\hline & -Among OFC borrowers & 6 & 0 & 0 & 0 & 6 & 0 & 0 & 0 \\
\hline \multirow{8}{*}{$\begin{array}{l}\text { FDI } \\
\text { (End 2015) }\end{array}$} & Share in global FDI & & & & & & & & \\
\hline & -Among AE borrowers & 4.4 & 1.1 & 4.8 & 8.2 & 20.9 & 5.9 & 2.7 & 3.9 \\
\hline & -Among EMDE borrowers & 14.1 & 0.4 & 0.9 & 1.5 & 12.2 & 1.9 & 1.9 & 0.1 \\
\hline & -Among OFC borrowers & 64.7 & 0.7 & 0.5 & 1.4 & 2.8 & 0.4 & 0.0 & 0.0 \\
\hline & Top lender (\# countries) & & & & & & & & \\
\hline & -Among AE borrowers & 4 & 0 & 1 & 4 & 16 & 1 & 1 & 0 \\
\hline & -Among EMDE borrowers & 16 & 0 & 4 & 4 & 5 & 2 & 1 & 0 \\
\hline & -Among OFC borrowers & 8 & 0 & 2 & 0 & 1 & 0 & 0 & 0 \\
\hline \multirow{8}{*}{$\begin{array}{l}\text { Portfolio } \\
\text { investment } \\
\text { (End 2017) }\end{array}$} & Share in global investment & & & & & & & & \\
\hline & -Among AE borrowers & 0.6 & 7.7 & 6.8 & 6.8 & 18.1 & 7.7 & 1.5 & 3.0 \\
\hline & -Among EMDE borrowers & 0.4 & 3.6 & 1.8 & 6.5 & 35.4 & 3.1 & 0.4 & 1.5 \\
\hline & -Among OFC borrowers & 12.7 & 4.8 & 0.9 & 7.9 & 35.1 & 1.4 & 0.1 & 1.6 \\
\hline & Top lender (\# countries) & & & & & & & & \\
\hline & -Among AE borrowers & 0 & 1 & 4 & 0 & 14 & 6 & 0 & 0 \\
\hline & -Among EMDE borrowers & 0 & 1 & 5 & 5 & 62 & 1 & 0 & 2 \\
\hline & -Among OFC borrowers & 0 & 0 & 0 & 0 & 9 & 0 & 0 & 0 \\
\hline
\end{tabular}


Annex Table 1. Cross-Border Banking, Trade and Investments: China Compared with Other Major Players in Advance Economies (AEs) and EMDEs (Continued)

\begin{tabular}{|c|c|c|c|c|c|c|c|c|c|}
\hline Positions & Type of measures & $\mathrm{NL}$ & IT & CA & AT & $\mathrm{AU}$ & $\mathrm{BE}$ & SE & DK \\
\hline \multirow{5}{*}{$\begin{array}{l}\text { Total bank } \\
\text { lending } \\
(2018 Q 2)\end{array}$} & Share in global lending & & & & & & & & \\
\hline & -Among AE borrowers & 6.2 & 3.3 & 4.1 & 0.6 & 2.1 & 1.1 & 3.3 & 1.3 \\
\hline & -Among EMDE borrowers & 2.8 & 2.4 & 1.6 & 1.6 & 1.2 & 0.8 & 0.6 & 0.2 \\
\hline & -Among OFC borrowers & 2.9 & 0.6 & 3.1 & 0.1 & 2.9 & 0.0 & 0.6 & 0.3 \\
\hline & Top lender (\# countries) & & & & & & & & \\
\hline \multirow{11}{*}{$\begin{array}{l}\text { USD-deno. } \\
\text { bank lending } \\
\text { (2018Q2) }\end{array}$} & -Among AE borrowers & 1 & 1 & 1 & 2 & 1 & 0 & 7 & 0 \\
\hline & -Among EMDE borrowers & 1 & 4 & 3 & 4 & 0 & 0 & 0 & 0 \\
\hline & -Among OFC borrowers & 0 & 0 & 1 & 0 & 0 & 0 & 0 & 0 \\
\hline & Share in global lending & & & & & & & & \\
\hline & -Among AE borrowers & 4.0 & 1.1 & 7.1 & 0.2 & 3.0 & 0.2 & 2.3 & 0.4 \\
\hline & -Among EMDE borrowers & 2.5 & 1.0 & 1.5 & 0.2 & 0.9 & 0.2 & 0.7 & 0.1 \\
\hline & -Among OFC borrowers & 3.4 & 0.4 & 3.0 & 0.1 & 3.6 & 0.1 & 0.6 & 0.1 \\
\hline & Top lender (\# countries) & & & & & & & & \\
\hline & -Among AE borrowers & 2 & 0 & 1 & 0 & 2 & 0 & 5 & 1 \\
\hline & -Among EMDE borrowers & 4 & 0 & 5 & 1 & 1 & 2 & 0 & 2 \\
\hline & -Among OFC borrowers & 0 & 0 & 2 & 0 & 0 & 0 & 0 & 0 \\
\hline \multirow{8}{*}{$\begin{array}{l}\text { Imports } \\
\text { (End 2016) }\end{array}$} & Share in global imports & & & & & & & & \\
\hline & -Among AE borrowers & 4.0 & 3.9 & 4.3 & 1.7 & 1.3 & 4.3 & 1.7 & 1.0 \\
\hline & -Among EMDE borrowers & 2.2 & 2.5 & 2.0 & 0.6 & 1.6 & 1.4 & 0.5 & 0.3 \\
\hline & -Among OFC borrowers & 3.1 & 0.3 & 0.4 & 0.1 & 2.2 & 2.7 & 0.5 & 0.3 \\
\hline & Top partner (\# countries) & & & & & & & & \\
\hline & -Among AE borrowers & 1 & 1 & 1 & 0 & 0 & 0 & 1 & 0 \\
\hline & -Among EMDE borrowers & 2 & 9 & 1 & 0 & 1 & 3 & 0 & 0 \\
\hline & -Among OFC borrowers & 1 & 0 & 0 & 0 & 1 & 0 & 0 & 0 \\
\hline \multirow{8}{*}{$\begin{array}{l}\text { Exports } \\
\text { (End 2016) }\end{array}$} & Share in global exports & & & & & & & & \\
\hline & -Among AE borrowers & 4.8 & 4.4 & 4.9 & 1.5 & 0.8 & 4.5 & 1.5 & 0.9 \\
\hline & -Among EMDE borrowers & 1.8 & 2.8 & 0.9 & 0.7 & 2.2 & 1.5 & 0.6 & 0.3 \\
\hline & -Among OFC borrowers & 1.1 & 1.2 & 0.4 & 0.1 & 1.4 & 0.6 & 0.2 & 0.1 \\
\hline & Top partner (\# countries) & & & & & & & & \\
\hline & -Among AE borrowers & 2 & 0 & 0 & 0 & 1 & 0 & 1 & 0 \\
\hline & -Among EMDE borrowers & 0 & 2 & 0 & 0 & 2 & 0 & 0 & 0 \\
\hline & -Among OFC borrowers & 1 & 0 & 0 & 0 & 1 & 0 & 0 & 0 \\
\hline \multirow{8}{*}{$\begin{array}{l}\text { FDI } \\
\text { (End 2015) }\end{array}$} & Share in global FDI & & & & & & & & \\
\hline & -Among AE borrowers & 5.0 & 2.0 & 3.7 & 0.9 & 3.3 & 1.7 & 0.3 & 0.7 \\
\hline & -Among EMDE borrowers & 1.3 & 0.6 & 3.0 & 1.5 & 2.6 & 0.3 & 0.0 & 0.0 \\
\hline & -Among OFC borrowers & 1.5 & 0.1 & 0.3 & 0.1 & 1.7 & 0.1 & 0.1 & 0.0 \\
\hline & Top lender (\# countries) & & & & & & & & \\
\hline & -Among AE borrowers & 1 & 1 & 0 & 0 & 1 & 0 & 0 & 0 \\
\hline & -Among EMDE borrowers & 0 & 0 & 1 & 1 & 0 & 2 & 0 & 0 \\
\hline & -Among OFC borrowers & 0 & 0 & 0 & 0 & 0 & 0 & 0 & 0 \\
\hline \multirow{8}{*}{$\begin{array}{l}\text { Portfolio } \\
\text { investment } \\
\text { (End 2017) }\end{array}$} & Share in global investment & & & & & & & & \\
\hline & -Among AE borrowers & 4.2 & 3.8 & 3.3 & 0.8 & 1.4 & 1.9 & 1.3 & 1.0 \\
\hline & -Among EMDE borrowers & 3.3 & 0.7 & 2.1 & 0.5 & 1.2 & 0.6 & 0.6 & 0.8 \\
\hline & -Among OFC borrowers & 2.5 & 0.2 & 1.9 & 0.1 & 1.3 & 0.1 & 0.8 & 0.5 \\
\hline & Top lender (\# countries) & & & & & & & & \\
\hline & -Among AE borrowers & 0 & 2 & 0 & 0 & 0 & 0 & 1 & 0 \\
\hline & -Among EMDE borrowers & 1 & 2 & 0 & 0 & 0 & 1 & 0 & 1 \\
\hline & -Among OFC borrowers & 0 & 0 & 0 & 0 & 0 & 0 & 0 & 0 \\
\hline
\end{tabular}


Annex Table 1. Cross-Border Banking, Trade and Investments: China Compared with Other Major Players in Advance Economies (AEs) and EMDEs (Continued)

\begin{tabular}{|c|c|c|c|c|c|c|c|c|c|}
\hline Positions & Type of measures & PT & GR & $\mathrm{CY}$ & NO & LU & $\mathrm{FI}$ & IE & $\mathrm{KR}$ \\
\hline \multirow{5}{*}{$\begin{array}{l}\text { Total bank } \\
\text { lending } \\
\text { (2018Q2) }\end{array}$} & Share in global lending & & & & & & & & \\
\hline & -Among AE borrowers & 0.3 & 0.2 & 0.0 & 0.7 & 0.3 & 0.1 & 0.4 & 0.3 \\
\hline & -Among EMDE borrowers & 0.2 & 0.2 & 0.1 & 0.1 & 0.1 & 0.0 & 0.0 & 2.1 \\
\hline & -Among OFC borrowers & 0.1 & 0.0 & 0.0 & 0.2 & 0.0 & 0.0 & 0.0 & 0.5 \\
\hline & Top lender (\# countries) & & & & & & & & \\
\hline \multirow{11}{*}{$\begin{array}{l}\text { USD-deno. } \\
\text { bank lending } \\
(2018 Q 2)\end{array}$} & -Among AE borrowers & 0 & 0 & 0 & 0 & 0 & 0 & 0 & 0 \\
\hline & -Among EMDE borrowers & 2 & 0 & 0 & 0 & 0 & 0 & 0 & 5 \\
\hline & -Among OFC borrowers & 0 & 0 & 0 & 0 & 0 & 0 & 0 & 0 \\
\hline & Share in global lending & & & & & & & & \\
\hline & -Among AE borrowers & 0.1 & 0.0 & 0.0 & 0.7 & 0.0 & 0.0 & 0.1 & 0.6 \\
\hline & -Among EMDE borrowers & 0.1 & 0.0 & 0.2 & 0.1 & 0.1 & 0.0 & 0.0 & 3.3 \\
\hline & -Among OFC borrowers & 0.0 & 0.0 & 0.0 & 0.2 & 0.0 & 0.0 & 0.0 & 0.8 \\
\hline & Top lender (\# countries) & & & & & & & & \\
\hline & -Among AE borrowers & 1 & 0 & 0 & 1 & 0 & 0 & 0 & 0 \\
\hline & -Among EMDE borrowers & 2 & 0 & 0 & 0 & 0 & 0 & 0 & 8 \\
\hline & -Among OFC borrowers & 0 & 0 & 0 & 0 & 0 & 0 & 0 & 0 \\
\hline \multirow{8}{*}{$\begin{array}{l}\text { Imports } \\
\text { (End 2016) }\end{array}$} & Share in global imports & & & & & & & & \\
\hline & -Among AE borrowers & 0.8 & 0.4 & 0.1 & 0.8 & 0.3 & 0.6 & 1.0 & 2.6 \\
\hline & -Among EMDE borrowers & 0.2 & 0.4 & 0.0 & 0.4 & 0.0 & 0.3 & 0.2 & 3.8 \\
\hline & -Among OFC borrowers & 0.0 & 0.1 & 0.0 & 0.2 & 0.0 & 0.1 & 0.2 & 3.3 \\
\hline & Top partner (\# countries) & & & & & & & & \\
\hline & -Among AE borrowers & 0 & 1 & 0 & 0 & 0 & 0 & 0 & 0 \\
\hline & -Among EMDE borrowers & 0 & 1 & 0 & 0 & 0 & 0 & 0 & 1 \\
\hline & -Among OFC borrowers & 0 & 0 & 0 & 0 & 0 & 0 & 0 & 0 \\
\hline \multirow{8}{*}{$\begin{array}{l}\text { Exports } \\
\text { (End 2016) }\end{array}$} & Share in global exports & & & & & & & & \\
\hline & -Among AE borrowers & 0.6 & 0.2 & 0.0 & 1.1 & 0.2 & 0.6 & 1.6 & 2.2 \\
\hline & -Among EMDE borrowers & 0.2 & 0.2 & 0.0 & 0.2 & 0.0 & 0.3 & 0.3 & 5.7 \\
\hline & -Among OFC borrowers & 0.0 & 0.2 & 0.0 & 0.2 & 0.0 & 0.1 & 0.2 & 5.6 \\
\hline & Top partner (\# countries) & & & & & & & & \\
\hline & -Among AE borrowers & 0 & 1 & 0 & 0 & 0 & 0 & 0 & 0 \\
\hline & -Among EMDE borrowers & 3 & 0 & 0 & 0 & 0 & 0 & 0 & 4 \\
\hline & -Among OFC borrowers & 0 & 0 & 0 & 0 & 0 & 0 & 0 & 1 \\
\hline \multirow{8}{*}{$\begin{array}{l}\text { FDI } \\
\text { (End 2015) }\end{array}$} & Share in global FDI & & & & & & & & \\
\hline & -Among AE borrowers & 0.5 & 0.2 & 0.0 & 0.9 & 1.5 & 0.6 & 2.2 & 1.0 \\
\hline & -Among EMDE borrowers & 0.6 & 0.0 & 0.2 & 0.4 & 0.2 & 0.1 & 0.0 & 1.1 \\
\hline & -Among OFC borrowers & 0.0 & 0.0 & 0.0 & 0.5 & 1.0 & 0.0 & 0.6 & 0.4 \\
\hline & Top lender (\# countries) & & & & & & & & \\
\hline & -Among AE borrowers & 0 & 0 & 0 & 0 & 0 & 0 & 0 & 1 \\
\hline & -Among EMDE borrowers & 1 & 0 & 0 & 0 & 0 & 0 & 0 & 1 \\
\hline & -Among OFC borrowers & 0 & 0 & 0 & 2 & 2 & 0 & 0 & 0 \\
\hline \multirow{8}{*}{$\begin{array}{l}\text { Portfolio } \\
\text { investment } \\
\text { (End 2017) }\end{array}$} & Share in global investment & & & & & & & & \\
\hline & -Among AE borrowers & 0.3 & 0.3 & 0.0 & 2.4 & 8.9 & 0.8 & 6.4 & 0.7 \\
\hline & -Among EMDE borrowers & 0.1 & 0.0 & 0.1 & 2.3 & 10.8 & 0.2 & 4.1 & 0.8 \\
\hline & -Among OFC borrowers & 0.1 & 0.0 & 0.0 & 1.6 & 7.2 & 0.1 & 3.5 & 1.5 \\
\hline & Top lender (\# countries) & & & & & & & & \\
\hline & -Among AE borrowers & 0 & 0 & 0 & 0 & 1 & 1 & 0 & 0 \\
\hline & -Among EMDE borrowers & 3 & 0 & 0 & 2 & 33 & 0 & 1 & 1 \\
\hline & -Among OFC borrowers & 0 & 0 & 0 & 0 & 2 & 0 & 0 & 0 \\
\hline
\end{tabular}


Annex Table 1. Cross-Border Banking, Trade and Investments: China Compared with Other Major Players in Advance Economies (AEs) and EMDEs (Continued)

\begin{tabular}{|c|c|c|c|c|c|c|c|c|c|}
\hline Positions & Type of measures & $\mathrm{BR}$ & IN & $\mathrm{RU}$ & ZA & TR & MY & $\mathrm{PH}$ & MX \\
\hline \multirow{5}{*}{$\begin{array}{l}\text { Total bank } \\
\text { lending } \\
\text { (2018Q2) }\end{array}$} & Share in global lending & & & & & & & & \\
\hline & -Among AE borrowers & 0.3 & 0.3 & 0.7 & 0.2 & 0.1 & 0.1 & 0.0 & 0.1 \\
\hline & -Among EMDE borrowers & 1.7 & 1.3 & 0.9 & 0.6 & 0.5 & 0.4 & 0.2 & 0.1 \\
\hline & -Among OFC borrowers & 1.1 & 0.4 & 0.2 & 0.1 & 0.2 & 0.4 & 0.1 & 0.0 \\
\hline & Top lender (\# countries) & & & & & & & & \\
\hline \multirow{11}{*}{$\begin{array}{l}\text { USD-deno. } \\
\text { bank lending } \\
\text { (2018Q2) }\end{array}$} & -Among AE borrowers & 0 & 0 & 1 & 0 & 0 & 0 & 0 & 0 \\
\hline & -Among EMDE borrowers & 0 & 1 & 2 & 4 & 0 & 0 & 0 & 0 \\
\hline & -Among OFC borrowers & 0 & 0 & 0 & 0 & 1 & 0 & 0 & 0 \\
\hline & Share in global lending & & & & & & & & \\
\hline & -Among AE borrowers & 0.7 & 0.3 & 0.9 & 0.2 & 0.1 & 0.1 & 0.1 & 0.1 \\
\hline & -Among EMDE borrowers & 2.9 & 1.9 & 0.7 & 0.8 & 0.4 & 0.4 & 0.3 & 0.2 \\
\hline & -Among OFC borrowers & 1.8 & 0.6 & 0.4 & 0.1 & 0.2 & 0.3 & 0.2 & 0.0 \\
\hline & Top lender (\# countries) & & & & & & & & \\
\hline & -Among AE borrowers & 0 & 0 & 1 & 0 & 0 & 0 & 0 & 0 \\
\hline & -Among EMDE borrowers & 0 & 1 & 1 & 4 & 0 & 0 & 0 & 0 \\
\hline & -Among OFC borrowers & 0 & 0 & 0 & 1 & 0 & 0 & 0 & 0 \\
\hline \multirow{8}{*}{$\begin{array}{l}\text { Imports } \\
\text { (End 2016) }\end{array}$} & Share in global imports & & & & & & & & \\
\hline & -Among AE borrowers & 1.0 & 1.5 & 1.3 & 0.5 & 1.3 & 0.8 & 0.4 & 3.9 \\
\hline & -Among EMDE borrowers & 1.2 & 3.8 & 1.6 & 0.7 & 1.7 & 1.6 & 0.8 & 2.2 \\
\hline & -Among OFC borrowers & 0.4 & 5.4 & 0.3 & 0.4 & 0.3 & 7.6 & 3.1 & 0.7 \\
\hline & Top partner (\# countries) & & & & & & & & \\
\hline & -Among AE borrowers & 0 & 0 & 0 & 0 & 0 & 0 & 0 & 0 \\
\hline & -Among EMDE borrowers & 3 & 14 & 5 & 3 & 2 & 0 & 0 & 0 \\
\hline & -Among OFC borrowers & 0 & 0 & 0 & 0 & 0 & 0 & 0 & 0 \\
\hline \multirow{8}{*}{$\begin{array}{l}\text { Exports } \\
\text { (End 2016) }\end{array}$} & Share in global exports & & & & & & & & \\
\hline & -Among AE borrowers & 1.0 & 1.4 & 2.0 & 0.4 & 1.0 & 0.9 & 0.4 & 4.9 \\
\hline & -Among EMDE borrowers & 2.1 & 2.7 & 2.8 & 0.8 & 1.3 & 1.7 & 0.3 & 0.6 \\
\hline & -Among OFC borrowers & 0.7 & 2.5 & 0.4 & 0.3 & 0.2 & 4.2 & 1.2 & 0.3 \\
\hline & Top partner (\# countries) & & & & & & & & \\
\hline & -Among AE borrowers & 0 & 0 & 3 & 0 & 0 & 0 & 0 & 0 \\
\hline & -Among EMDE borrowers & 4 & 4 & 6 & 8 & 4 & 0 & 0 & 0 \\
\hline & -Among OFC borrowers & 0 & 0 & 0 & 0 & 0 & 0 & 0 & 0 \\
\hline \multirow{8}{*}{$\begin{array}{l}\text { FDI } \\
\text { (End 2015) }\end{array}$} & Share in global FDI & & & & & & & & \\
\hline & -Among AE borrowers & 2.9 & 1.8 & 0.9 & 0.8 & 0.5 & 0.5 & 0.2 & 3.5 \\
\hline & -Among EMDE borrowers & 3.1 & 1.6 & 1.3 & 1.0 & 2.1 & 0.5 & 0.3 & 2.2 \\
\hline & -Among OFC borrowers & 0.4 & 1.7 & 1.0 & 0.1 & 0.1 & 1.5 & 0.2 & 0.2 \\
\hline & Top lender (\# countries) & & & & & & & & \\
\hline & -Among AE borrowers & 3 & 0 & 1 & 0 & 1 & 0 & 0 & 1 \\
\hline & -Among EMDE borrowers & 1 & 1 & 3 & 6 & 2 & 0 & 1 & 1 \\
\hline & -Among OFC borrowers & 1 & 1 & 1 & 0 & 0 & 0 & 0 & 0 \\
\hline \multirow{8}{*}{$\begin{array}{l}\text { Portfolio } \\
\text { investment } \\
\text { (End 2017) }\end{array}$} & Share in global investment & & & & & & & & \\
\hline & -Among AE borrowers & 0.1 & 0.0 & 0.2 & 0.4 & 0.0 & 0.1 & 0.0 & 0.1 \\
\hline & -Among EMDE borrowers & 0.0 & 0.0 & 0.1 & 0.1 & 0.0 & 0.2 & 0.1 & 0.1 \\
\hline & -Among OFC borrowers & 0.1 & 0.0 & 0.2 & 0.3 & 0.0 & 2.9 & 0.1 & 0.0 \\
\hline & Top lender (\# countries) & & & & & & & & \\
\hline & -Among AE borrowers & 0 & 0 & 1 & 0 & 0 & 0 & 0 & 0 \\
\hline & -Among EMDE borrowers & 0 & 0 & 0 & 2 & 0 & 0 & 0 & 0 \\
\hline & -Among OFC borrowers & 0 & 0 & 0 & 0 & 0 & 0 & 0 & 0 \\
\hline
\end{tabular}


Annex Table 2. Variable Description

\begin{tabular}{|c|c|c|c|}
\hline Variables (short name) & Variable description & Unit/Value & Source/Comment \\
\hline Total lending & Cross-border lending, all currencies & In of USD mn & $\begin{array}{l}\text { BIS locational banking statistics (by } \\
\text { nationality) }\end{array}$ \\
\hline USD lending & $\begin{array}{l}\text { Cross-border lending denominated } \\
\text { in USD }\end{array}$ & In of USD mn & $\begin{array}{l}\text { BIS locational banking statistics (by } \\
\text { nationality) }\end{array}$ \\
\hline Colony & $\begin{array}{l}\text { Indicator of colonial relationship } \\
\text { between pairs of countries (after } \\
\text { 1945) }\end{array}$ & $0 / 1$ & CEPII database \\
\hline Language & $\begin{array}{l}\text { Indicator of Common Official } \\
\text { Language (using at least } 9 \% \text { of the } \\
\text { population between two countries) }\end{array}$ & $0 / 1$ & $\underline{\text { CEPII database }}$ \\
\hline Trade & Sum of exports and imports & In of USD mn & $\underline{\text { UN Comtrade Database }}$ \\
\hline Investment & $\begin{array}{l}\text { Total Portfolio Investment } \\
\text { (Equity+Debt) }\end{array}$ & In of USD mn & $\underline{\mathrm{IMF}, \mathrm{CPIS}}$ \\
\hline FDI & Foreign direct investment & In of USD mn & Damgaard and Elkjaer (2017) \\
\hline SDistance & $\begin{array}{l}\text { Simple distance between capitals of } \\
\text { country pairs }\end{array}$ & In of km & CEPII database \\
\hline WDistance & $\begin{array}{l}\text { Weighted distance between capitals } \\
\text { of country pairs }\end{array}$ & In of km & $\begin{array}{l}\text { With weights as share of lending from } \\
\text { different locations of bank's affiliates at } \\
\text { home and abroad. See Graph } 3 \text { for a } \\
\text { more detailed description. }\end{array}$ \\
\hline \multicolumn{4}{|c|}{$\begin{array}{l}\text { Note: The aggregation by nationality in the case of Chinese banks captures only cross-border claims of those banks from Mainland } \\
\text { China and their global network of affiliates. It does not include, for example, Chinese banks, which are domestically owned in Hong } \\
\text { Kong SAR. We use end- } 2016 \text { data as lagged values for the variables on bilateral economic ties (Trade, Investment and FDI) to mitigate } \\
\text { endogeneity concerns. In order to retain observations with small values of bilateral ties, we use } \ln (\mathrm{X}+1) \text { in the regressions. }\end{array}$} \\
\hline
\end{tabular}

\section{CInternational Monetary Fund. Not for Redistribution}


Annex Table 3. Data Sample

Parent Countries/Jurisdictions (39) with the Number of Counterparty Borrower Countries in Parenthesis

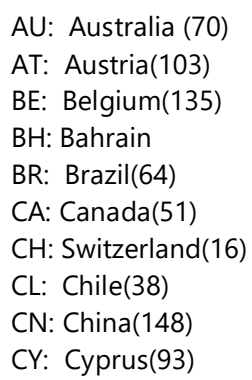

AU: Australia (70)

AT: Austria(103)

BE: Belgium(135)

BH: Bahrain

BR: Brazil(64)

CA: Canada(51)

$\mathrm{CH}$ : Switzerland(16)

CL: Chile(38)

CN: China(148)

CY: Cyprus(93)

DE: Germany(113)
DK: Denmark(51)
ES: Spain(14)
FI: Finland(16)
FR: France(56)
GB: United Kingdom(80)
GR: Greece(84)
HK: Hong Kong SAR(14)
ID: Indonesia(54)
IE: Ireland(59)

IN: India(148)

IT: Italy(143)

JP: Japan(30)

KR: Korea(140)

LU: Luxembourg(30)

MO: Macao SAR(18)

MX: Mexico(23)

MY: Malaysia (15)

NL: Netherlands(39)

NO: Norway(73)

\author{
PA: Panama(38) \\ PH: Philippines(50) \\ PT: Portugal(20) \\ RU: Russia(81) \\ SE: Sweden(90) \\ SG: Singapore(49) \\ TR: Turkey(101) \\ US: United States(113) \\ ZA: South Africa(87)
}

\section{Cross-Border Counterparty Borrower Countries/Jurisdictions (185) Split into}

\section{A. Advanced Economies (AEs, 31 of $\mathbf{3 6}$ jurisdictions):}

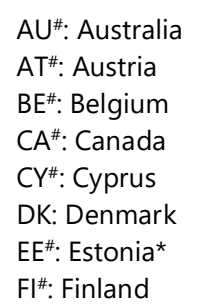

\author{
$F R^{\#}$ : France \\ $D E^{\#}:$ Germany \\ $\mathrm{GR}^{*}:$ Greece \\ IS\#: Iceland \\ IE: Ireland \\ IT": Italy \\ JP: Japan \\ LV\#: Latvia*
}

LT\#: Lithuania*
LU\#: Luxembourg $^{\#}$ MT\#: Malta $^{\#}$
NL\#: Netherlands
NZ\#: New Zealand
NO: Norway
PT: Portugal
SM: San Marino

\author{
SK\#: Slovak Republic* \\ SI": Slovenia* \\ ES": Spain \\ SE: Sweden \\ $\mathrm{CH}^{\#}$ : Switzerland \\ GB: United Kingdom \\ US: United States
}

\section{B. Offshore Financial Centres (OFCs, 11 of 21 jurisdictions)}

BS: Bahamas

BB: Barbados

\author{
$H K^{\#}$ : Hong Kong SAR \\ LB: Lebanon* \\ MO: Macao SAR
}

MU: Mauritius
PA: Panama
WS: Samoa
SG\#: Singapore*

VU: Vanuatu

\section{Emerging Markets and Developing Economies (EMDEs, 143 of 159 jurisdictions)}

\begin{tabular}{|c|c|c|c|}
\hline AF: Afghanistan* & BN: Brunei Darussalam* & Cl: Côte d'Ivoire & GE: Georgia* \\
\hline$A L^{\#}:$ Albania* & BG: Bulgaria* & HR: Croatia* & GH: Ghana \\
\hline DZ: Algeria & BF: Burkina Faso & CZ: Czech Republic* & GD: Grenada \\
\hline AO: Angola & BI: Burundi & DJ: Djibouti & GT: Guatemala \\
\hline $\mathrm{AR}^{\#}$ : Argentina & KH: Cambodia* & CD: Dem. Rep. of Congo & GN: Guinea \\
\hline $\mathrm{AM}^{\#}$ : Armenia* & CM: Cameroon & DM: Dominica & GW: Guinea-Bissau \\
\hline AZ: Azerbaijan* & CV: Cape Verde & DO: Dominican Republic & GY: Guyana \\
\hline BD: Bangladesh* & CF: Central African Rep. & EC: Ecuador & HT: Haiti \\
\hline BY\#: Belarus* & TD: Chad & EG: Egypt* & HN: Honduras \\
\hline BZ: Belize & $\mathrm{CL}^{\#}$ : Chile & GQ: Equatorial Guinea & $\mathrm{HU}^{\#:}$ : Hungary* \\
\hline BJ : Benin & CN: China* & ER: Eritrea & IN: India* \\
\hline BT: Bhutan & $\begin{array}{l}\text { TW: Taiwan Province of } \\
\text { China }\end{array}$ & ET: Ethiopia & ID\#: Indonesia* \\
\hline BO: Bolivia & CO: Colombia & SV: El Salvador & IR: Iran \\
\hline BA: Bosnia and Herzegovina* & KM: Comoros Islands & FJ: Fiji & IQ: Iraq* \\
\hline BW: Botswana & CG: Congo, Republic of & GA: Gabon & IL: Israel* \\
\hline BR\#: Brazil & CR: Costa Rica & GM: Gambia & JM: Jamaica \\
\hline JO: Jordan* & MD: Moldova* & $\mathrm{QA}^{\#:}$ : Qatar* & TZ: Tanzania \\
\hline KZ\#: Kazakhstan* & MN\#: Mongolia* & RO: Romania* & TH$^{\#: ~ T h a i l a n d * ~}$ \\
\hline KE: Kenya & ME: Montenegro* & RU\#: Russia* & TG: Togo \\
\hline KI: Kiribati & MA: Morocco & RW: Rwanda & TO: Tonga \\
\hline
\end{tabular}




$\begin{array}{llll}\text { KR: Korea } & \text { MZ: Mozambique } & \text { ST: Sao time and Principe } & \text { TT: Trinidad and Tobago } \\ \text { KW: Kuwait* } & \text { MM: Myanmar* } & \text { SA: Saudi Arabia* } & \text { TN: Tunisia } \\ \text { KG: Kyrgyz Republic* } & \text { NA: Namibia } & \text { SN: Senegal } & \text { TR*: Turkey* } \\ \text { LA: Lao P.D.R*. } & \text { NR: Nauru } & \text { RS: Serbia* } & \text { TM: Turkmenistan } \\ \text { LS: Lesotho } & \text { NP: Nepal* } & \text { SC: Seychelles } & \text { TV: Tuvalu } \\ \text { LR: Liberia } & \text { NI: Nicaragua } & \text { SL: Sierra Leone } & \text { UG: Uganda } \\ \text { LY: Libya } & \text { NE: Niger } & \text { SB: Solomon Islands } & \text { UA: } \text { Ukraine* }^{*} \\ \text { MK: Macedonia FYR* } & \text { NG: Nigeria } & \text { SO: Somalia } & \text { AE*: United Arab Emirates* } \\ \text { MG: Madagascar } & \text { OM: Oman* } & \text { ZA*: South Africa } & \text { UY: Uruguay } \\ \text { MW: Malawi } & \text { PK*: Pakistan* } & \text { LK\#: Sri Lanka* } & \text { UZ\#: Uzbekistan* } \\ \text { MY\#: Malaysia* } & \text { PW: Palau } & \text { LC: St: Lucia } & \text { VE: Venezuela } \\ \text { MV: Maldives } & \text { PG: Papua New Guinea } & \text { VC: St. Vincent } \& & \text { VN: Vietnam* } \\ & & \text { Grenadines } & \\ \text { ML: Mali } & \text { PY: Paraguay } & \text { SD: Sudan } & \text { YE: Yemen* } \\ \text { MH: Marshall Islands } & \text { PE: Peru } & \text { SR: Suriname } & \text { ZM: Zambia } \\ \text { MR: Mauritania } & \text { PH: Philippines* } & \text { SY: Syria } & \text { ZW: Zimbabwe } \\ \text { MX: Mexico } & \text { PL: Poland* } & \text { TJ: Tajikistan* } & \end{array}$

Note: \# indicates Swap line agreement with China; a total of 50 countries. * indicates BRI 2015 countries, and the list also includes Bhutan (BT), Iran (IR), Maldives (MV), Palestine Territory (PS), Syria (SY), Timor Leste (TL) and Turkmenistan (TM); a total of 65 countries.

List of 31 Excluded Borrower Countries/Jurisdictions (=216-185)

\begin{tabular}{|c|c|c|}
\hline AEs: Advanced Economies (5) & \multicolumn{2}{|c|}{ EMDEs: Emerging markets \& developing economies(16) } \\
\hline AD: Andorra & BQ: Bonaire, Sint Eustatius and Saba & PS - Palestinian Territory \\
\hline FO: Faeroe Islands & 1W: British overseas territories & SS - South Sudan \\
\hline GL: Greenland & CU: Cuba & SH - St. Helena \\
\hline LI: Liechtenstein & FK: Falkland Islands & SZ - Swaziland \\
\hline VA: Vatican City & PF: French Polynesia & TL - Timor-Leste \\
\hline & FM: Micronesia & TC - Turks and Caicos Islands \\
\hline & NC: New Caledonia & PU - US Pacific islands \\
\hline & KP: North Korea & WF: Wallis and Futuna \\
\hline Share of excluded BCs within AEs: $0.1 \%$ & \multicolumn{2}{|l|}{ Share of excluded BCs within EMDEs: $1.1 \%$} \\
\hline \multicolumn{2}{|c|}{ Offshore centres (10) } & \multirow{7}{*}{$\begin{array}{l}\text { Share of all } \mathbf{3 1} \text { excluded BCs: } \\
9.3 \% \text { of total cross-border claims } \\
\text { on all } 216 \text { BCs }\end{array}$} \\
\hline AW: Aruba & GG: Guernsey & \\
\hline BM: Bermuda & IM: Isle of Man & \\
\hline KY: Cayman Islands & JE : Jersey & \\
\hline CW: Curacao & SX: Sint Maarten & \\
\hline Gl: Gibraltar & 1Z: West Indies UK & \\
\hline $\begin{array}{l}\text { Share of excluded BCs within offshore } c \\
\text { Islands) }\end{array}$ & $56.1 \%(41 \%$ is only due to Cayman & \\
\hline
\end{tabular}




\section{References}

Allen, F, J. Qian, C. Zhang, and M. Zhao, 2012, “China's financial system: Opportunities and challenges," NBER Working paper, No. 17828 (Cambridge, MA: National Bureau of Economic Research).

Andrade, S C and V Chhaochharia, 2010, "Information immobility and foreign portfolio investment," Review of Financial Studies, Vol. 23, Issue 6, pp. 2429-2463.

Aviat, A and N Coeurdacier, 2007, "The geography of trade in goods and asset holdings," Journal of International Economics, Vol. 71, pp. 22-51.

Avdjiev, S., McCauley, R. N., \& Shin, H. S., 2016, Breaking free of the triple coincidence in international finance, Economic Policy, Vol. 3, Issue 87, pp. 409-451.

Bank for International Settlements, 2019, Reporting Guidelines for the BIS International Banking Statistics, July.

Bénétrix, A. S., McCauley, R. N., McGuire, P. M., \& von Peter, G., 2019, "Financial deglobalisation in banking?," Journal of International Money and Finance, Vol. 94 (June), pp. 116-131.

Blonigen, B., 2001, "In Search of Substitution Between Foreign Production and Exports," Journal of International Economics, Vol. 53, Issue 1, pp. 81-104.

Bosshardt, J, and E Cerutti, 2020, "Why Did Public Banks Lend More During the Global Financial Crisis?,” IMF Working paper, No. 20/84 (Washington: International Monetary Fund).

Brei, M and P von Peter, 2018, “The Distance Effect in Banking and Trade," Journal of International Money and Finance, Vol. 81 (March), pp. 116-137.

Buch, C, 1999, “Why Do Banks Go Abroad? Evidence from German Data,” Kiel Working Paper, No. 948 (Kiel: Kiel Institute for the World Economy).

—_ 2002, “Are Banks Different? Evidence from International Data," International Finance, Vol 5, Issue 1, pp. 97-114.

— C C Koch, and M Koetter, 2014, "Should I Stay or Should I go? Bank Productivity and Internationalization Decisions" Journal of Banking and Finance, Vol. 42, pp 266-82.

Caballero, J, C Candelaria, and G Hale, 2018, "Bank linkages and international trade," Journal of International Economics, Vol. 115, Issue C, pp. 30-47. 
Cerutti, E, 2015, "Drivers of Cross-Border Banking Exposures During the Crisis," Journal of Banking and Finance, Vol. 55, pp. 340-357.

—, C Koch, and S. K. Pradhan, 2018, "The Growing Footprint of EMDE Banks in the International Banking System," BIS Quarterly Review, December.

_, and H Zhou, 2017, "The Global Banking Network in the Aftermath of the Crisis: Is There Evidence of De-globalization?,” IMF Working Paper No. 17/232

(Washington: International Monetary Fund).

— Regionalization Trend?," IMF Working Paper No. 18/46 (Washington: International Monetary Fund).

— Giant”, VoxEU, February 9, 2018.

Cheung Y-W, R. N. McCauley, and C Shu, 2019, "Geographic Spread of Currency Trading: the Renminbi and Other EM Currencies?,” BIS Working Papers No. 806 (Basel: Bank for International Settlements).

Claessens, S, and N van Horen, 2015, “The Impact of the Global Financial Crisis on Banking Globalization,” IMF Economic Review, Vol. 63, Issue 4, pp. 868-918.

Claessens, S, and N van Horen, 2020, "Foreign Banks and Trade," Journal of Financial Intermediation (forthcoming).

Coppola, A, M Maggiori, B Neiman, and J Schreger, 2020, "Redrawing the Map of Global Capital Flows: The Role of Cross-Border Financing and Tax Havens," mimeo.

Gopinath, G, E Boz, C Casas, F J Díez, P-O Gourinchas, and M Plagborg-Møller, 2020, "Dominant Currency Paradigm," American Economic Review, Vol. 110, Issue 3, pp. 677-719.

Damgaard J, and T Elkjaer, 2017, “The Global FDI Network: Searching for Ultimate Investors," IMF Working Paper No. 17/258 (Washington: International Monetary Fund).

Hale, G, T Kapan and C Minoiu (2019): Shock Transmission Through Cross-Border Bank Lending: Credit and Real Effects, The Review of Financial Studies, December 2019.

— 2012, "Bank Relationships, Business Cycles, and Financial Crises," Journal of International Economics, Vol. 88, pp. 312-325. 
Horn, S, C M Reinhart, and C Trebesch, 2020, “China's Overseas Lending,” NBER Working Paper (revised) No 26050 (May) (Cambridge, MA: National Bureau of Economic Research).

McGuire P, and A Van Rixtel, 2012, "Shifting Credit Patterns in Emerging Asia," BIS Quarterly Review, December, pp. 17-18.

Mian, A, 2006, "Distance Constraints: The Limits of Foreign Lending in Poor Economies," The Journal of Finance, Vol. 61, Issue 3, pp. 1465-1505.

Minoiu, C, and J Reyes, 2013, “A Network Analysis of Global Banking: 1978-2010,” Journal of Financial Stability, Vol. 9, pp. 168-184.

Niepmann, F., 2015, “Banking Across Borders," Journal of International Economics, Vol. 96, Issue 2, pp. 244-265.

Karolyi, A, K Ng, and E Prasad, 2020, “The Coming Wave: Where Do Emerging Markets Put Their Money?," Journal of Financial and Quantitative Analysis, Vol. 55, Issue 4 (June), pp. 1369-1414.

Lane, P, 2006, “Global Bond Portfolios and EMU," International Journal of Central Banking, Vol. 2, Issue 2, pp. 1-23.

—_, and G M Milesi-Ferretti, 2008, "International Investment Patterns," Review of Economics and Statistics, Vol. 90, Issue 3, pp. 538-549.

McGuire, P., and G. von Peter, 2016, "The Resilience of Banks' International Operations," BIS Quarterly Review, pp. 65-78.

Okawa, Y, and E van Wincoop, 2012, “Gravity in International Finance," Journal of International Economics, Vol. 87, pp. 205-215.

Petersen, M A, and R Rajan, 2002, “Does Distance Still Matter? The Information Revolution in Small Business Lending," Journal of Finance, Vol. LVII, No. 6 (December), pp. $2533-2570$.

Portes, R, and H Rey, 2005, “The Determinants of Cross-Border Equity Flows,” Journal of International Economics, Vol. 65, pp. 260-296.

Santos Silva, J, and S Tenreyro, 2006, "The Log of Gravity," The Review of Economics and Statistics, Vol. 88, Issue 4, pp. 641-658.

Schipke, A, 2019, The Future of China's Bond Market (Washington: International Monetary Fund). 